\title{
Effect of Perfluorooctanesulfonic acid (PFOS) on immune cell development and function in mice
}

\author{
Luisa Torres ${ }^{1, \#}$, Amie Redko ${ }^{1}$, Candice Limper ${ }^{1}$, Brian Imbiakha ${ }^{1}$, Sue Chang ${ }^{2}$, and Avery \\ August ${ }^{1, *}$ \\ 1'Department of Microbiology \& Immunology, Cornell University, Ithaca, NY 14853, USA; \\ 23M Company, St. Paul, MN 55144, USA
}

${ }^{*}$ Correspondence: Avery August, Department of Microbiology \& Immunology, College of Veterinary Medicine, VMC 5171, Cornell University, Ithaca, NY 14853, (607) 253-3402 (Ofc), (607) 253-4058 (Fax), email: averyaugust@cornell.edu

\#Present Address: LifeOmic, Indianapolis, IN

Key words: PFOS, influenza, immune system 


\begin{abstract}
Perfluorinated compounds, such as Perfluoroctane sulfonic acid (PFOS) are compounds containing carbon chains where hydrogens have been replaced with fluorines, and belong to a larger family known as Per- and polyfluoroalkyl substances (PFAS). The strength of the carbonfluorine bond makes perfluorinated compounds extremely resistant to environmental degradation. Due to the persistent nature of PFOS, research has been directed to elucidating possible health effects of PFOS on humans and laboratory animals. Here we have explored the effects of PFOS exposure on immune development and function in mice. We exposed adult wild-type mice to 3 and $1.5 \mu \mathrm{g} / \mathrm{kg} / \mathrm{day}$ of PFOS for 2 and 4 weeks, respectively, and examined the effects of PFOS exposure on populations of T cells, B cells, and granulocytes. These doses of PFOS resulted in serum levels of approximately $100 \mathrm{ng} / \mathrm{ml}$ with no weight loss during exposure. We find that PFOS does not affect T-cell development during this time. However, while PFOS exposure reduced immune cell populations in some organs, it also led to an increase in the numbers of cells in others, suggesting possible relocalization of cells. We also examined the effect of PFOS on the response to influenza virus infection. We find that exposure to PFOS at $1.5 \mu \mathrm{g} / \mathrm{kg} / \mathrm{day}$ of PFOS for 4 weeks does not affect weight loss or survival, nor is viral clearance affected. Analysis of antibody and T cell specific antiviral responses indicate that at this concentration, PFOS does not suppress the immune cell development or antigen specific immune response.
\end{abstract}




\section{Introduction}

Perfluorooctanesulfonyl fluoride (POSF)-based compounds are a class of surfactant chemicals that have been used in a wide variety of industrial and consumer applications ${ }^{1}$. Perfluorooctanesulfonate (PFOS, $\mathrm{C}^{8} \mathrm{~F}^{17} \mathrm{SO}^{3-}$ ) is the end-stage metabolite for POSF-based chemistry and the strength of the carbon-fluorine bond makes it extremely stable and resistant to environmental degradation ${ }^{2}$. PFOS is ubiquitously distributed in the environment and does not metabolize under normal physiological conditions, with bioaccumulation potential in both wildlife and humans. Observations in multiple species indicate that PFOS is slowly eliminated with serum half-lives of approximately 1 - 2 months for rodents, 4 months for non-human primates, and 3 5 years for humans ${ }^{3-5}$.

Due to the persistent nature of PFOS, research has been directed at evaluating possible health effects of exposure to $\mathrm{PFOS}^{6}$. In epidemiological studies in humans, exposure to PFOS have been reported to be associated with several health effects, and meta-analyses and/or critical reviews of this literature suggest association with lower birthweight ${ }^{7}{ }^{8}$, infertility ${ }^{9}$, altered thyroid function in pregnant women and children ${ }^{10}$; higher cholesterol ${ }^{11}$, and immunological effects ${ }^{12}$. With regards to potential effects on the immune system, a systematic review of the literature was conducted by the National Toxicology Program (NTP), which concluded that PFOS is "presumed to be an immune hazard to humans" ${ }^{12}$ based on reports of PFOS-mediated suppression of the antibody response in animal studies, and epidemiological studies in humans. While the evidence for an effect of PFOS on the immune system was based on findings of suppression of the antibody response and was found to be substantial by the NTP, there was less evidence from experimental animals that PFOS suppresses disease resistance and natural killer (NK) cell activity. Furthermore, the NTP reports indicate that the mechanism(s) for such PFOS-associated immunotoxicity was not well-understood. In addition, among the supporting studies cited by NTP, the seemingly high level of PFOS dose(s) used in the studies with laboratory animals often resulted in significant body weight loss ${ }^{12}$, and the accompanying stress and elevated levels of 
corticosteroids (a known confounder for immune response ${ }^{13}$ ), that accompanies these high dose treatments cannot be excluded ${ }^{12}$.

Here we have evaluated the potential immunotoxicity of exposure to PFOS in wild-type C57BI/6 mice after repeated oral treatments for either 2 weeks or 4 weeks, using doses of PFOS that did not lead to weight loss in the animals. We examined the development of immune cells, including T cell development in the thymus, as well as B cell and granulocyte development in the bone marrow and spleen. We also evaluated the effect of PFOS exposure on the immune response to influenza virus infection. 


\section{Materials and Methods}

\section{Material}

All chemicals used in this study were reagent-grade. Potassium perfluorooctanesulfonate (K+PFOS) was obtained from 3M Company (St. Paul, MN). The details of its purity $(88.9 \%)$ and analytical characterization are described in Chang et al. ${ }^{14}$.

\section{PFOS dose formulation and analysis}

$\mathrm{K}^{+}$PFOS was prepared in vehicle $(0.5 \%$ Tween 20 in deionized water) at either $0.3 \mu \mathrm{g} / \mathrm{mL}$ or $0.6 \mu \mathrm{g} / \mathrm{mL}$; and with a daily dosing volume of $5 \mathrm{~mL}$ per $\mathrm{kg}$ body weight, it corresponded to a daily targeted dose of either $1.5 \mu \mathrm{g} / \mathrm{kg}$ body weight/day or $3 \mu \mathrm{g} / \mathrm{kg}$ body weight /day, respectively. The dosing solutions and the serum samples were analyzed for PFOS concentration by LCMS/MS based on previous methods ${ }^{14,15}$. Briefly, matrix-matched standard curves were prepared and ${ }^{18} \mathrm{O}_{2}$-PFOS was used as internal standard for all extractions. All standards and samples underwent solid phase extraction prior to LC-MS/MS analyses. API 6500 mass spectrometer (AB SCIEX, Redwood City, California) with Turbo Ion Spray (pneumatically assisted electrospray ionization source) that operated in a negative ion mode was used for this study, and chromatography analysis was conducted with a Mac-Mod ACE C-18 HPLC column (2.1 mm i.d. $\times 75 \mathrm{~mm}, 5 \mu \mathrm{m}$ particle size) at $0.25 \mathrm{~mL} / \mathrm{min}$ under gradient condition $(95 \% / 5 \% 2 \mathrm{mM}$ ammonium acetate/acetonitrile and acetonitrile). All source parameters were optimized under the conditions according to manufacturer's guidelines. Transition ions monitored were: (1) PFOS: $499 \rightarrow 80 \mathrm{~m} / \mathrm{z}$; and (2) Internal Standard ${ }^{18} \mathrm{O}_{2}$-PFOS: $503 \rightarrow 84 \mathrm{~m} / \mathrm{z}$. Concentration of PFOS in the vehicle solution ( $0.5 \%$ Tween 20 in water) was also measured and was below the lower limit of quantification of $5 \mathrm{ng} / \mathrm{mL}$.

\section{Mice}


Adult male and female wild-type C57BL/6 mice bred at Cornell University were used this study. The mice were approximately eight weeks old and weighed approximately $20-25$ grams at the start of the treatment. All experimental procedures were reviewed and approved by the Institutional Animal Care and Use Committee and Institutional Review Board at Cornell University and conformed to Guide for the Care and Use of Laboratory Animals ${ }^{16}$.

\section{Study design for PFOS exposure}

2-week PFOS exposure: Male and female C57BI/6 mice ( $\mathrm{n}=6-7 /$ group) were administered daily with either vehicle (0.5\% Tween 20 in water) or $\mathrm{K}^{+}$PFOS (referred to hereafter as PFOS) at 3 $\mu \mathrm{g} / \mathrm{kg} / \mathrm{day}$ for 14 days via oral gavage. The theoretical total administered dose (TAD) was $42 \mu \mathrm{g}$ PFOS/kg body weight after 14 daily oral administrations. At the end of the exposure period (one day after last dose), animals were euthanized under $\mathrm{CO}_{2}$ asphyxiation and blood was collected from the abdominal aorta. Blood samples were left at room temperature for 40 minutes and processed to serum after centrifugation (2500 rpm, $20 \mathrm{~min}$ ). Serum samples were stored frozen at $-80^{\circ} \mathrm{C}$ pending further analysis. Thymus, spleen, liver, Peyer's patches, and bone marrow were also collected from all mice and further processed for lymphocyte isolation as described below (see organ collection and lymphocyte isolation).

4-week PFOS exposure: Male and female C57BI/6 mice ( $n=4-7 / g r o u p)$ were administered daily with either vehicle $(0.5 \%$ Tween 20 in water) or PFOS at $1.5 \mu \mathrm{g} / \mathrm{kg} / \mathrm{day}$ for 28 days via oral gavage. After 28 consecutive daily treatments, the theoretical total administered dose (TAD) was $42 \mu \mathrm{g}$ PFOS/kg body weight as well. At the end of the exposure period (one day after last dose), animals were euthanized and blood and organs collected as previously described for 2-week PFOS exposure.

Influenza virus infection post 4-week PFOS treatment: Both male and female C57BI/6 mice were used in this study. In experiment \#1, mice ( $n=4-5 /$ group) were administered daily with either vehicle $(0.5 \%$ Tween 20 in water) or PFOS at $1.5 \mu \mathrm{g} / \mathrm{kg} /$ day for 28 days via oral gavage. One 
day after the last vehicle or PFOS treatment, mice were infected with mouse influenza virus strain A/WSN/33(H1N1) intranasally (1e6 pfu/mouse). Body weights were monitored daily for 11 days post infection followed by euthanization. Animals were euthanized as previously described and bronchoalveolar lavage collected from lungs, and blood, lungs, liver and spleen collected as described above. Serum and BAL samples were stored frozen at $-80^{\circ} \mathrm{C}$ until analyzed.

In experiment \#2, mice ( $\mathrm{n}=10 /$ group) were administered daily with either vehicle $(0.5 \%$ Tween 20 in water) or PFOS at $1.5 \mu \mathrm{g} / \mathrm{kg} /$ day for 28 days via oral gavage. One day after the last vehicle or PFOS treatment, mice were infected with mouse influenza virus strains $A / W S N / 33(H 1 N 1)(W S N-$ $\left.\mathrm{OVA}_{I}\right)$ and influenza A/WSN/33(H1N1)(WSN-OVA $\left.{ }_{\|}\right)$intranasally (2e4 pfu/mouse). Influenza A/WSN/33(H1N1)(WSN-OVA $)$ is a recombinant influenza virus carrying the peptide epitope $\mathrm{OVA}_{257-264}$ from the model antigen Ovalbumin, and influenza A/WSN/33(H1N1) (WSN-OVA $\left.{ }_{\|}\right)$was a recombinant influenza virus carrying the peptide epitope $\mathrm{OVA}_{323-339}$ from the model antigen Ovalbumin ${ }^{17,18}$. Body weights, euthanization and tissue collections were as described above.

\section{Organ collection and lymphocyte isolation}

Thymus, spleen, liver, Peyer's patches, and bone marrow were collected from euthanized mice. The spleen and thymus where passed through a $100-\mu \mathrm{m}$ cell strainer and crushed with the plunger of a $3 \mathrm{ml}$ syringe to get a single-cell suspension that was collected in $5 \mathrm{ml}$ of complete RPMI medium. The liver was injected with $10 \mathrm{ml}$ of PBS followed by $5 \mathrm{ml}$ of $0.05 \%$ collagenase A and Dispase II in complete medium. The homogenized tissue was filtered and centrifuged for 5 min at 400 rcf. $5 \mathrm{ml}$ of Lympholyte-M was added to the $5 \mathrm{ml}$ of PBS containing the resuspended pellet and centrifuged for 20 minutes at 1200 rcf. Lymphocytes were obtained from the interface layer. Lymphocytes were isolated from the Peyer's patches as previously described ${ }^{19}$. The bone marrow was flushed with $1 \mathrm{ml}$ of complete RPMI medium using a $1 \mathrm{ml}$ syringe and a 23-gauge needle to obtain a single cell suspension of lymphocytes. Cells were counted with an automated cell counter, surfaced-stained, and analyzed by flow cytometry. 


\section{Hemagglutination inhibition (HAl) assays}

Hemagglutination inhibition assays were performed as described ${ }^{20}$. In brief, a $1 \%(v / v)$ suspension of chicken red blood cells in PBS was used to assay hemagglutination of influenza virus and 2 fold dilutions of serum from mice infected with the mixture of WSN-OVA, and WSN$\mathrm{OVA}_{\|}$. Sera were incubated with 4 hemagglutination units of WSN virus. The HI titer was defined as the reciprocal of the highest serum dilution inhibiting hemagglutination.

\section{Antibodies for flow cytometry}

T- cell panel: APC-Cy7- TCRß (BD Biosciences), efluor 450-CD4, PerCP-Cy5.5-CD8a, PE NKT, PeCy7 NK1.1, FITC CD44, AF700 CD62L, APC TCRyס. Granulocyte panel: Pacific Blue Ly6G, PE Siglec-F, APC CD11c, AF700 MHCII, CF594 CD11b, APC Cy7 c-kit, BV510 F4/80,

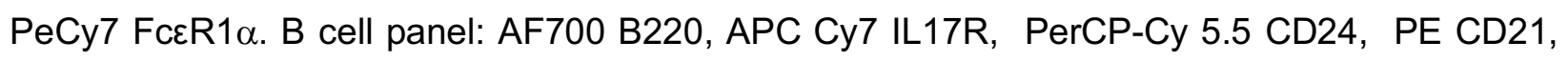
PECy7 CD23, APC IgM. iNKT cells were identified using CD1d/ $\alpha$-galactosyl ceramide tetramers from the NIH Tetramer Core Facility (https://tetramer.yerkes.emory.edu/). OVA-antigen specific T cells in influenza A/WSN/33(H1N1) (WSN)-OVA $A_{\iota}$ influenza A/WSN/33(H1N1) (WSN)-OVA infected mice were identified using MHC-class II and class I OVA/tetramers that identify OVAspecific $\mathrm{CD}^{+}$and $\mathrm{CD}^{+} \mathrm{T}$ cells ${ }^{21}{ }^{22}$, also obtained from the $\mathrm{NIH}$ Tetramer Core Facility (https://tetramer.yerkes.emory.edu/).

\section{Flow Cytometry}

Surface staining of live cells was done in the presence of anti-CD16/32 (clone 93; Fc block) and fixable viability dye. Flow cytometry data were acquired on LSRII, FACS Aria II or Fusion systems (BD Biosciences), and analyzed in FlowJo (Tree Star, Ashland, OR). All analyses were performed on fixable viability dye negative singlet population. 


\section{Statistical analysis}

All statistics were performed using GraphPad Prism 8 for Mac. ANOVA or two-tailed Student's $t$ tests with Welch's correction for samples having possibly unequal variances was used to determine significance between control and experimental groups. Data were presented as mean \pm SEM. Data were considered statistically significant when $p<0.05$. 


\section{Results}

\section{PFOS concentrations in serum samples after 2-week or 4-week PFOS treatments}

Male and female mice were orally administered with either vehicle or PFOS daily for 14 days $(3 \mu \mathrm{g} / \mathrm{kg} /$ day $)$ or 28 days $(1.5 \mu \mathrm{g} / \mathrm{kg} /$ day $)$, in order to achieve comparable serum PFOS levels. After either 14 days or 28 days of PFOS exposure at $3 \mu \mathrm{g} / \mathrm{kg} / \mathrm{day}$ or $1.5 \mu \mathrm{g} / \mathrm{kg} / \mathrm{day}$, respectively, the mean serum PFOS concentrations were $(116 \mathrm{ng} / \mathrm{m} ; \pm 2.8(\mathrm{SEM})) \mathrm{ng} / \mathrm{mL}$ and $(99.6 \pm 4.4($ SEM $)) \mathrm{ng} / \mathrm{mL}$, respectively There was a statistical significant difference between the mean serum PFOS levels of the 2 and 4 week exposures (Fig. 1A).

\section{PFOS exposure at $3 \mu \mathrm{g} / \mathrm{kg} /$ day PFOS for 2 weeks or $1.5 \mu \mathrm{g} / \mathrm{kg} /$ day for 4 weeks does not affect body weight or selected organ weights}

The body weight of the PFOS-exposed mice were monitored daily. After 2 weeks or 4 weeks of PFOS exposure at $3 \mu \mathrm{g} / \mathrm{kg} / \mathrm{day}$ or $1.5 \mu \mathrm{g} / \mathrm{kg} /$ day, respectively, we did not observe significant changes in body weight at the end of either treatment period (Fig. 1B). Analysis of the thymus, spleen, and liver indicated that at these concentrations, PFOS does not affect the weights of these organs (Fig. 1C).

\section{Effect of 2-week or 4-week exposure to PFOS on T cell development in the thymus}

T lymphocytes develop from hematopoietic stem cells that differentiate into lymphoid progenitors in the bone marrow, which migrate to the thymus, where they initially lack most of the surface molecules characteristic of mature T cells. These cells give rise to populations of $\alpha \beta T$ cells and $ү \delta$ T cells. T cells are initially double negative for co-receptors CD4 and CD8 and later differentiate into $\alpha \beta T$ cells and $y \delta T$ cells, with a CD4/CD8 double positive intermediate stage before becoming single positive CD4 and CD8 $\alpha \beta$ T cell depending on the class of MHC molecules they encounter, followed by exit from the thymus and circulation in the periphery ${ }^{23}$. To determine 
the effect of PFOS exposure on T lymphocyte development, we analyzed thymocytes in the C57BL/6 male and female mice exposed to $3 \mu \mathrm{g} / \mathrm{kg} /$ day PFOS for 2 weeks or $1.5 \mu \mathrm{g} / \mathrm{kg} / \mathrm{day}$ for 4 weeks. Regardless of exposure duration, PFOS did not affect the numbers of thymocytes (Fig. 2A). Flow cytometric analysis of thymocyte subpopulations (Fig. 2B), indicated that exposure also did not affect the percentages of double negative or double positive thymocytes for CD4 and CD8, indicating that PFOS exposure at this concentration did not affect T cell development (Fig. 2C).

\section{Effect of 2-week or 4-week exposure to PFOS on T and B cell development in the spleen}

Once $\mathrm{T}$ lymphocytes develop in the thymus, they exit and migrate to peripheral organs, including the spleen and lymph nodes. We next analyzed T lymphocyte development in the spleen of the mice exposed to $3 \mu \mathrm{g} / \mathrm{kg} /$ day PFOS for 2 weeks or $1.5 \mu \mathrm{g} / \mathrm{kg} / \mathrm{day}$ for 4 weeks for T cell subsets as indicated in figure $3 \mathrm{~A}$. We found no effect of PFOS at this concentration on total splenocytes (Fig. 3A), nor was there an effect on the percentage of $\alpha \beta$ T cells, $ү \delta$ T cells, invariant Natural killer T cells (iNKT cells), NK cells, and B cells (Fig. 3B, as analyzed by flow cytometric analysis exemplified in Fig. 3C). There was also no difference in the percentage of $\mathrm{CD}^{+}$and $\mathrm{CD}^{+} \alpha \beta$ T cells (Fig. 3D) after 2 and 4 weeks of exposure. However, after 2 weeks of PFOS exposure, we observed a reduction in the percentage of naïve $C D 8^{+} \alpha \beta T$ cells, with an accompanying increase in memory $\mathrm{CD}^{+} \alpha \beta \mathrm{T}$ cells in the spleen, which was not observed in the $\mathrm{CD}^{+} \mathrm{T}$ cell compartment, or in either population at 4 weeks of exposure to PFOS (Fig. 3D, E). In addition, after 2 weeks of PFOS exposure, but not at 4 weeks, we observed an increase in the percentage of NK cells but not in the total number of NK cells (Fig. 3D). Analysis of B cell development for immature, mature and marginal zone B cells in the spleen revealed a reduction in the percentage of mature B cells in spleens from both 2 week and 4 week PFOS exposed animals, although the numbers of these cells were not affected (Fig. 3F). 
Effect of 2-week or 4-week exposure to PFOS on T and B cell development in the bone marrow

As discussed above, hematopoietic stem cells differentiate into lymphoid progenitors, which develop into T and B cells. T cells develop in the thymus, and B cells develop in the bone marrow. In addition, some subsets of T cells, largely memory derived can also be found in the bone marrow. To further explore B and T cell development in the bone marrow, we analyzed cells collected from the bone marrow of mice exposed to $3 \mu \mathrm{g} / \mathrm{kg} / \mathrm{day}$ PFOS for 2 weeks or 1.5 $\mu \mathrm{g} / \mathrm{kg} / \mathrm{day}$ for 4 weeks for B and T cell subsets. We found no effect of PFOS exposure for 2 or 4 weeks at this concentration on total leukocyte numbers in the bone marrow (Fig. 4A, D). There was also no effect on the number of granulocytes and lymphocytes, including $T$ and $B$ cells after 2 weeks of exposure (Fig. 4B). After 2 weeks of exposure there was no effect on the proportion of $\mathrm{B}$ cells, and $\mathrm{CD}^{+}$and $\mathrm{CD}^{+}$subpopulations of $\mathrm{T}$ cells (Fig. 4C), nor on naïve and memory $\mathrm{CD}^{+} \mathrm{T}$ cells, although there was an increase in the proportion of $\mathrm{CD}^{+}$naïve $\mathrm{T}$ cells, and a decrease in the proportion $\mathrm{CD}^{+}$memory T cells (Fig. 4C). We also found that after 4 weeks of exposure there was a decrease in the proportion of $\mathrm{CD} 4^{+} \mathrm{T}$ cells and an increase in $\mathrm{CD} 8^{+}$memory T cells (Fig. 4F), as well as an increase in proportion of the NK cells at 4 weeks, although we found no difference in the number of NK cells (Fig. 4G).

\section{Effect of 2-week or 4-week exposure to PFOS on T cells in the liver}

The liver has been shown to be a target for PFOS at higher concentrations, and while we did not observe changes in liver weights at this concentration, we examined T cells in this organ. We found that mice exposed to PFOS for 2 but not 4 weeks had higher numbers of total liver lymphocytes (Fig. 5A, D), although there was no difference in number or percentages of liver T cells, iNKT cells or NK cells (Fig. 5B, E). There was also no difference in percentages of CD4 ${ }^{+}$ and $\mathrm{CD}^{+}$subpopulations of T cells (Fig. 5C, F), NKT cells, NK cells, nor on naïve and memory 
$\mathrm{CD}^{+} \mathrm{T}$ cells, with the exception of a decrease in percentages of $\mathrm{CD} 8^{+}$naïve $\mathrm{T}$ cells after 2 but not 4 weeks of exposure (Fig. 5C, F).

\section{4-week exposure to $1.5 \mu \mathrm{g} / \mathrm{kg} /$ day PFOS does not affect viral clearance and the immune response to influenza virus infection}

The immune response to influenza virus is critical for protection against infection. We therefore determined the effect of PFOS exposure on the response to influenza virus infection. 8week-old C57BL/6 male and female mice were exposed to vehicle or $1.5 \mu \mathrm{g} / \mathrm{kg} / \mathrm{day}$ PFOS for 4 weeks. Twenty four hours after the last exposure, animals were infected with influenza virus (Influenza A/WSN/33(H1N1) (Fig. 6A-D), or a mixture of influenza A/WSN/33(H1N1) (WSN-OVA $)$ and influenza A/WSN/33(H1N1) (WSN-OVA ${ }_{\| 1}$ ), or PBS as control (Fig. 6E-J). In the first experiment where mice were infected with Influenza A/WSN/33(H1N1) (Fig. 6A-D), PFOS exposure did not significantly affect virus induced weight loss (Fig. 6A). Similarly, there was no effect of PFOS exposure at this concentration on the amount of virus present in the lung upon sacrificing at 11 days post infection (Fig. 6B). There was also no difference in the number of inflammatory cells, T cells and granulocytes, in the lung (Fig. 6C), nor the proportion of these cells in the BALF or lung (Fig. 6D). Similarly, there was no difference in the proportion of CD4 ${ }^{+}$or $\mathrm{CD}^{+} \mathrm{T}$ cells, nor $\mathrm{CD} 4^{+} \mathrm{CD} 44^{\mathrm{Hi}}, \mathrm{CD} 8^{+} \mathrm{CD} 44^{\mathrm{Hi}}$ (with $\mathrm{CD} 44^{\mathrm{Hi}}$ cells representing activated or memory cells) in BALF (Fig. 6D, top panels), although PFOS exposed mice exhibited reduced proportions of $\mathrm{CD} 4^{+} \mathrm{T}$ cells and increased $\mathrm{CD} 8^{+} \mathrm{T}$ cells, with increased proportion of $\mathrm{CD} 4^{+} \mathrm{CD} 44^{\mathrm{Hi}}$ in the lung (Fig. 6D, bottom panels). In addition, there was no difference in the proportion of TNF $\alpha^{+} \mathrm{CD}^{+}$or $\mathrm{CD}^{+} \mathrm{T}$ cells in the lung (as analyzed by intracellular cytokine staining following PMA/lonomycin stimulation in vitro) (Fig. 6D).

In a second experiment mice were infected with a mixture of influenza $A / W S N / 33(H 1 N 1)$ $\left(\mathrm{WSN}-\mathrm{OVA} \mathrm{A}_{l}\right.$ ) and influenza A/WSN/33(H1N1) (WSN-OVA $\left.{ }_{\|}\right)$so as to follow the antigen specific $\mathrm{CD}^{+}$and $\mathrm{CD}^{+} \mathrm{T}$ cell response using MHC-class I/OVA and class II/OVA tetramers that identify 
OVA-specific CD4 ${ }^{+}$and $\mathrm{CD} 8^{+}$T cells (Fig. 6E-J). As in the experiment where mice were infected with influenza A/WSN/33(H1N1) (see Fig. 6A), infection with WSN-OVA $A_{\text {I }}$ and WSN-OVA following PFOS exposure did not significantly affect virus induced weight loss (Fig. 6E). Similarly, there was no effect of PFOS exposure at this concentration on the amount of virus present in the lung upon sacrificing at 11 days post infection (Fig. 6F). There was also no difference in the number of inflammatory cells in the BALF collected from flu infected mice regardless of exposure to PFOS (Fig. 6G). Analysis of the antigen specific T cell response using the MHC-class I/OVA and class II/OVA tetramers revealed no difference in the percentage of antigen specific CD4 ${ }^{+}$or $\mathrm{CD}^{+} \mathrm{T}$ cells in the spleens of these mice, although PFOS exposed mice exhibited a higher number of antigen specific $\mathrm{CD} 4^{+} \mathrm{T}$ cells $(\mathbf{F i g} . \mathbf{6 H}, \mathbf{I})$. Analysis of serum for neutralizing antibodies generated against the virus by Hemagglutinin Agglutination Inhibition (HAl) assay revealed no difference in anti-viral titers between vehicle and PFOS exposed mice at this concentration (Fig. 6J). 


\section{Discussion}

The persistent nature of PFOS has led to the investigation of possible health effects of exposure in humans and laboratory animals. Here we have explored the effects of PFOS exposure ( 3 and $1.5 \mu \mathrm{g} / \mathrm{kg} / \mathrm{day}$ of PFOS for 2 and 4 weeks, respectively (equivalent to $\sim 100 \mathrm{ng} / \mathrm{ml}$ serum PFOS)) on immune cell development and function in mice. We find that at this concentration, oral exposure of mice to PFOS did not result in weight loss during the 2 and 4 week exposure. We also find that PFOS does not affect T-cell development during this time. However, we find that PFOS exposure reduced immune cell populations in some organs, and increased their numbers in others. We find that exposure of mice to PFOS at $1.5 \mu \mathrm{g} / \mathrm{kg} / \mathrm{day}$ of PFOS for 4 weeks does not affect weight loss or survival following infection with influenza virus, nor does it affect viral clearance, nor the antigen specific antibody and $\mathrm{T}$ cell response. These results suggest that exposure of mice to PFOS at 3 and $1.5 \mu \mathrm{g} / \mathrm{kg} / \mathrm{day}$ of PFOS for 2 and 4 weeks does not suppress the immune system or its response to viral infection.

Based on reports of PFOS-mediated suppression of the antibody response in animal studies, and epidemiological studies in humans, the NTP previously concluded that PFOS is "presumed to be an immune hazard to humans" ${ }^{12}$. Previous studies using exposure to higher levels of PFOS have suggested an effect on the immune system, with either no effect on immune cell numbers, reduced thymic and splenic $\mathrm{T}$ (including reduced $\mathrm{CD} 8^{+}$and $\mathrm{CD} 4^{+} \mathrm{T}$ cells) and $\mathrm{B}$ cells, reduced or no effect on T cell proliferation, reduced IL2 and IFN $\gamma$, (Th1 cytokines) increased IL4 (Th2 cytokine), decreased TNF $\alpha$, no effect on IL10, increased or no effect on IL1 $\beta$, increased or decreased IL6, increased or decreased NK cell activity (depending on exposure concentration), increased serum $\lg$, or reduced $\lg M$, but increased $\lg G, \lg _{1}$, and $\lg E$ levels in response to SRBC injection ${ }^{24-34}$. In many of these studies, animals were in general exposed to PFOS concentrations $>5 \mathrm{mg} / \mathrm{kg} /$ day and in some cases $>50 \mathrm{mg} / \mathrm{kg} / \mathrm{day}$. At high levels of PFOS exposure (e.g. $>20 \mathrm{mg} / \mathrm{kg} /$ day for 7 days, equivalent to $>280,000 \mathrm{ng} / \mathrm{ml}$ ) and in a dose-dependent manner, 
mice experienced decreased food intake, increased liver mass, weight loss and serum corticosteroid; the latter could affect immune populations ${ }^{33,35}$. At concentrations in the range used in this study, little to no effect on liver weights and body weights, or on the immune system has been reported ${ }^{30,36}$. Here, following exposure to 2 week or 4 weeks leading to serum concentrations of $\sim 100-125 \mathrm{ng} / \mathrm{ml}$ (for a TAD of $0.14 \mathrm{mg} / \mathrm{kg}$ after 4 weeks), with no weight loss or changes in organ weights, we found no effect on T cell development in the thymus, including on the percentages of double negative, double positive or CD4 and CD8 single positive thymocytes.

Analysis of spleen also revealed no effect on total cell numbers, however after 2 weeks, but not 4 weeks of PFOS exposure, we observed a reduction in the percentage of naïve $\mathrm{CD}^{+} \alpha \beta$ T cells, with an accompanying increase in memory $\mathrm{CD}^{+} \alpha \beta \mathrm{T}$ cells, which was not observed in the $\mathrm{CD}^{+} \mathrm{T}$ cell compartment. This transient change could be due to changes in these populations, or changes in the recirculation patterns of these $\mathrm{T}$ cell subsets. Indeed, we also observed an increase in the $\mathrm{CD}^{+}$naïve $\mathrm{T}$ cells, and a decrease in $\mathrm{CD}^{+}$memory $\mathrm{T}$ cells in the bone marrow after 2 weeks of PFOS exposure. In addition, after 2 weeks of PFOS exposure, but not after 4 weeks, we observed an increase in the percentage of NK cells but not in the total number of NK cells. Analysis of B cells in the spleen revealed a reduction in percentage of mature B cells in the spleens from both 2 week and 4 week PFOS exposed animals, although the number of these cells were not affected. It is possible that accompanying changes in other B cell subsets also occur that affect the proportions of these B cell subsets. The observed changes may also reflect changes in recirculation patterns of different cell subsets that may occur during normal immune homeostasis.

Our analysis of the effect of PFOS on bone marrow populations of $\mathrm{T}$ cells revealed a decrease in proportion of CD4 ${ }^{+} \mathrm{T}$ cells and an increase in $\mathrm{CD}^{+}$memory $\mathrm{T}$ cells after 4 weeks of PFOS exposure, as well as an increase in the proportion of NK cells, although again, no difference in the number of NK cells. No effect was observed on immature and mature B cells. Studies of exposure of mice to oral PFOS (in food) have revealed dose-dependent increase in PFOS 
multiple tissues including blood, liver and bone marrow, with liver retaining the highest levels ${ }^{37}$. In the liver, we found an increase in the number of lymphocytes at 2 weeks, but not at 4 weeks, with no difference in the numbers or percentages of liver T cells, iNKT cells or NK cells. We also found a transient decrease in naïve $C D 8^{+} \mathrm{T}$ cells after 2 weeks, but not after 4 weeks of exposure. Other researchers have examined the effects of PFOS on bone marrow cells (at levels of $0.002 \% \mathrm{w} / \mathrm{w}$ PFOS for 10 days, equivalent to $3.1 \mathrm{mg} / \mathrm{kg}$ ) and have also reported no effect on cell numbers or B cell development ${ }^{38}$. Our work has also found no effect of PFOS exposure on the numbers or percentages of these cells at the levels of PFOS exposure used in these experiments.

Little work has been done exploring the effects of PFOS on response to infection in mice. Suo et al, exposed mice to much higher levels of PFOS ( $2 \mathrm{mg} / \mathrm{kg} / \mathrm{day}$ ) and examined the response to Citrobacter rodentium (CR) infection, and found enhanced early response to $\mathrm{CR}$, but eventual delayed clearance of bacteria ${ }^{39}$. However, these high levels of PFOS exposure may have other effects as discussed previously. Guruge et al reported that doses in a similar range to what was used in this study at 5 ( $189 \mathrm{ng} / \mathrm{ml}$ serum levels) and $25 \mathrm{mg} / \mathrm{kg} / \mathrm{day} \quad(\sim 670 \mathrm{ng} / \mathrm{ml}$ serum levels) PFOS exposure was accompanied by increased weight loss and mortality following infection with the mouse adapted influenza A virus (100 pfu A/PR/8/34 (H1N1) strain $)^{40}$. However, there was no analysis of immune response in these experiments ${ }^{40}$.

Here, we have also explored the effect of PFOS exposure on the response to influenza infection, using the mouse adapted A/WSN/33 (H1N1) strain of influenza. We found no significant effect on infection-induced weight loss, virus levels in the lung, number of lung $\mathrm{T}$ cells and granulocytes. We did find that PFOS exposed mice exhibited reduced proportions of lung CD4 ${ }^{+}$ $\mathrm{T}$ cells and increased $\mathrm{CD}^{+} \mathrm{T}$ cells, although there was an increased proportion of activated/memory $\mathrm{CD} 4^{+} \mathrm{T}$ cells (as determined by higher levels of CD44). In addition, there was no difference in ex vivo stimulated production TNF $\alpha$ by $T$ cells in the lung. We also analyzed $T$ cell specific antigen responses to flu infection by using recombinant influenza viruses A/WSN/33 (H1N1) (WSN-OVA $A_{l}$ ) and influenza A/WSN/33(H1N1) (WSN-OVA $A_{I I}$. We found that PFOS 
exposure did not significantly affect the percentage of antigen specific CD4 ${ }^{+}$or $\mathrm{CD}^{+} \mathrm{T}$ cells in the spleens of infected mice, although PFOS exposed mice exhibited a higher number of antigen specific CD4 ${ }^{+} \mathrm{T}$ cells. Finally, our analysis of serum from infected for virus specific antibodies, revealed no effect of PFOS exposure. Our results suggest that at this concentration of PFOS, there is no suppression of the antiviral response to flu infection. It is possible that our results differ due to the different strains of mice used (our studies used C57BI/6, the previous study used B6C3F1), as different strains of mice exhibit differential susceptibility to flu infection ${ }^{41,42}$. The viral strain may also be a potential explanation as our study used A/WSN/33 (H1N1) and the previous study used A/PR/8/34 (H1N1)), although they are reported to have similar LD $50 \mathrm{~S}$ in mice ${ }^{41}$.

\section{Conclusion}

In this study, we have examined the effects of subchronic exposure of PFOS on immune cell development and function in mice. At approximately $100-125 \mathrm{ng} / \mathrm{mL}$ of serum PFOS, it has minimal effects on lymphocyte subpopulation proportions or numbers, and does not suppress the immune response to influenza infection. Further studies in laboratory animals, as well as in humans, need to be considered in order to fully determine the potential effects of PFOS on immune system development and response. 


\section{Acknowledgement}

We thank members in the August lab for helpful discussions. This work was supported by an unrestricted university research grant from 3M Company (to A.A.). B.I is supported by the Cornell IMSD program (R25GM125597 to A.A.). C.L. is a Cornell Sloan Scholar.

\section{Author contributions}

L.T., A.R., C.L., S.C. and B.I. conducted experiments; L.T., B.I, S.C. and A.A. designed research, L.T., B.I, S.C. and A.A. analyzed data, and L.T., S.C. and A.A. wrote the manuscript.

\section{Disclosures}

S.C. is an employee of $3 \mathrm{M}$ Company. A.A. receives research support from $3 \mathrm{M}$ Company. The other authors have no financial conflicts of interest. 
Figure Legends

Figure 1. PFOS exposure at $3 \mu \mathrm{g} / \mathrm{kg} /$ day PFOS for 2 weeks or $1.5 \mu \mathrm{g} / \mathrm{kg} /$ day for 4 weeks does not significantly affect body weight. (A) WT C57BI/6 mice were exposed to vehicle or PFOS at $3 \mu \mathrm{g} / \mathrm{kg} /$ day for 2 weeks or $1.5 \mu \mathrm{g} / \mathrm{kg} /$ day for 4 weeks by oral gavage. At the end of the exposures, serum PFOS concentrations were determined. Mean \pm SEM, $n=6$ (vehicle exposed) and $n=7$ (PFOS exposed) for 2 weeks of exposure, ${ }^{*} p<0.0001$ vs vehicle 2 weeks exposed mice, Mean \pm SEM, $n=7$ (vehicle exposed) and $n=4$ (PFOS exposed), ${ }^{*} p<0.0001$ vs vehicle 4 weeks exposed mice, * $p<0.00052$ week vs 4 week PFOS exposed mice. (B) Mice in (A) were weighed daily and percent original weight plotted. 2 weeks (left panel) or 4 weeks (right panel), mean \pm SEM, $n=7$ (vehicle exposed) and n=8 (PFOS exposed) for 2 weeks of exposure and $n=7$ (vehicle exposed) and $n=5$ (PFOS exposed) for 4 weeks of exposure. (C) The indicated organs from the mice described in $(A)$ were weighed. Mean $\pm S E M, n=5$ (vehicle exposed) and $n=6$ (PFOS exposed) for 2 weeks of exposure and $n=7$ (vehicle exposed) and $n=5$ (PFOS exposed).

Figure 2. PFOS exposure at $3 \mu \mathrm{g} / \mathrm{kg} /$ day PFOS for 2 weeks or $1.5 \mu \mathrm{g} / \mathrm{kg} /$ day for 4 weeks does not significantly affect T cell development in the thymus. (A) Thymi from WT C57BI/6 mice exposed to vehicle or PFOS at $3 \mu \mathrm{g} / \mathrm{kg} /$ day for 2 weeks (left panel) or $1.5 \mu \mathrm{g} / \mathrm{kg} / \mathrm{day}$ for 4 weeks (right panel) were collected and thymocytes enumerated. Mean \pm SEM, $n=5$ (vehicle exposed) and $n=6$ (PFOS exposed) for 2 weeks of exposure and $n=7$ (vehicle exposed) and $n=5$ (PFOS exposed). (B) Example flow cytometric plots of thymocytes and gating strategy to identify thymocyte populations. (C) CD4/CD8 double negative (DN), CD4/CD8 double positive, CD4 single positive (SP) and CD8SP populations plotted. Mean \pm SEM, $n=5$ (vehicle exposed) and $\mathrm{n}=6$ (PFOS exposed) for 2 weeks of exposure and $n=7$ (vehicle exposed) and $n=5$ (PFOS exposed). 
Figure 3. Effect of PFOS exposure at $3 \mu \mathrm{g} / \mathrm{kg} /$ day PFOS for 2 weeks or $1.5 \mu \mathrm{g} / \mathrm{kg} / \mathrm{day}$ for 4 weeks on splenocyte populations. (A) Splenocytes from WT C57BI/6 mice exposed to vehicle or PFOS at $3 \mu \mathrm{g} / \mathrm{kg} / \mathrm{day}$ for 2 weeks (left panel) or $1.5 \mu \mathrm{g} / \mathrm{kg} / \mathrm{day}$ for 4 weeks (right panel) were collected and enumerated. Mean \pm SEM, n=5 (vehicle exposed) and n=5 (PFOS exposed) for 2 weeks of exposure and $n=7$ (vehicle exposed) and $n=5$ (PFOS exposed). (B) Analysis of the percentages of subpopulations of lymphocytes in spleens from mice described in (A). Mean \pm SEM, $n=5$ (vehicle exposed) and n=5 (PFOS exposed) for 2 weeks of exposure and $n=7$ (vehicle exposed) and $n=5$ (PFOS exposed). (C) Example flow cytometric plots to identify $T$ cell populations $\left(\gamma \delta, \alpha \beta, \mathrm{CD}^{+}, \mathrm{CD}^{+}, \mathrm{NKT}, \mathrm{NK}\right.$, and $\mathrm{CD} 4^{+}$and $\mathrm{CD} 8^{+}$naïve $\left(\mathrm{CD} 44^{\mathrm{lo}} \mathrm{CD} 62 \mathrm{~L}^{\mathrm{hi}}\right)$ and memory $\left(\mathrm{CD} 44^{\mathrm{Hi}}\right)$ populations. (D) Analysis of the percentages of (left to right) $\mathrm{CD} 4^{+}$and $\mathrm{CD} 8^{+} \mathrm{T}$ cells (panel 1), naïve and memory subsets of $\mathrm{CD}^{+}$and $\mathrm{CD}^{+}$(panels $2 \& 3$ ) and iNKT and NK cells (panel 4), and number of NK cells (panel 5) in spleens from 2 week exposed mice described in (A). Mean \pm SEM, $n=5$ (vehicle exposed) and $n=5$ (PFOS exposed), * $p<0.0001$ naïve CD8 ${ }^{+}$ cells at 2 weeks, ${ }^{*} p=0.0368$ for memory $C D 8^{+}$cells at 2 weeks vehicle vs PFOS exposed mice, ${ }^{*} p=0.0014$ for NK cells at 2 weeks, vehicle vs PFOS exposed mice. (E) Analysis of the percentages of (left to right) $C D 4^{+}$and $C D 8^{+} T$ cells (panel 1), naïve and memory subsets of CD4 ${ }^{+}$ and $\mathrm{CD}^{+}$(panels $2 \& 3$ ) and $i$ NKT and NK cells (panel 4) in spleens from 4 week exposed mice described in (A). Mean \pm SEM, $n=5$ (vehicle exposed) and $n=5$ (PFOS exposed). (F) Analysis of the percentages of (left to right) splenic immature, mature and marginal zone B cells after 2 weeks (panel 1) or 4 weeks of exposure (panel 2). Number of splenic immature, mature and marginal zone B cells after 2 weeks (panel 3 ) or 4 weeks of exposure (panel 4). Mean \pm SEM, n=5 (vehicle exposed) and $n=5$ (PFOS exposed), ${ }^{*} p=0.0003$ for percent of mature B cells at 2 weeks, and ${ }^{*} p=0.0014$ for percent of mature B cells at 4 weeks vehicle vs PFOS exposed mice. 
Figure 4. Effect of PFOS exposure at $3 \mu \mathrm{g} / \mathrm{kg} /$ day PFOS for 2 weeks or $1.5 \mu \mathrm{g} / \mathrm{kg} / \mathrm{day}$ for 4 weeks on bone marrow lymphocyte populations. (A, D) Bone marrow lymphocytes from WT C57BI/6 mice exposed to vehicle or PFOS at $3 \mu \mathrm{g} / \mathrm{kg} /$ day for 2 weeks (A) or $1.5 \mu \mathrm{g} / \mathrm{kg} / \mathrm{day}$ for 4 weeks (D) were collected and enumerated. Mean \pm SEM, $n=5$ (vehicle exposed) and n=5 (PFOS exposed) for 2 weeks of exposure and $n=7$ (vehicle exposed) and $n=5$ (PFOS exposed) for 4 weeks. (B) Analysis of the percentages of subpopulations of lymphocytes in spleens from mice described in (A). (C) Analysis of the percentages of (left to right) B cells (panel 1), $\alpha \beta$ T cells (panel 2), $C D 4^{+}$and $C D 8^{+}$naïve and memory subsets (panels $3 \& 4$ ) in spleens from 2 week exposed mice described in $(A)$. ${ }^{*} p=0.0005$ for naïve $C D 8^{+}$cells at 2 weeks vehicle vs PFOS exposed mice. (E) Analysis of the percentages of subpopulations of lymphocytes in spleens from mice described in (D). (F) Analysis of the percentages of (left to right) B cells (panel 1), $\alpha \beta$ T cells (panel 2), $C D 4^{+}$and $C D 8^{+}$naïve and memory subsets (panels $3 \& 4$ ) in spleens from 4 week exposed mice described in (D). ${ }^{*} p=0.0107$ for $\mathrm{CD}^{+} \alpha \beta$ T cells and ${ }^{*} p=0.0382$ for memory CD8 ${ }^{+}$ cells for vehicle vs PFOS exposed mice. (G) Analysis of the percentages (panels 1\&3) and number (panel 2\&4) of $i$ NKT and NK cells in spleens from 2 week exposed mice described in (A), (panels 1\&2), or 4 week exposed mice described in (D), (panels $3 \& 4$ ). * $p=0.0149$ for NK from 2 week exposed vehicle vs PFOS exposed mice.

Figure 5. Effect of PFOS exposure at $3 \mu \mathrm{g} / \mathrm{kg} /$ day PFOS for 2 weeks or $1.5 \mu \mathrm{g} / \mathrm{kg} / \mathrm{day}$ for 4 weeks on liver lymphocyte populations. (A, D) Number (Mean \pm SEM) of liver lymphocytes from WT C57BI/6 mice exposed to vehicle or PFOS at $3 \mu \mathrm{g} / \mathrm{kg} / \mathrm{day}$ for 2 weeks ( $\mathrm{n}=5$ (vehicle exposed) and $n=6$ (PFOS exposed)) $(\mathbf{A}, p=0.0450)$, or $1.5 \mu \mathrm{g} / \mathrm{kg} /$ day for 4 weeks $(n=7$ (vehicle exposed) and $n=5$ (PFOS exposed)) (D). (B, E) Number (Mean \pm SEM) of liver $\alpha \beta$ T cells (left panel), iNKT cells (middle panel) or NK cells (right panel). (C, F) Percentage of CD4 ${ }^{+}, \mathrm{CD}^{+}$(left 
panel), $\mathrm{CD}^{+}$and $\mathrm{CD}^{+}$naïve and memory cells (middle panels, $\mathrm{p}=0.0320$ for naive $\mathrm{CD} 8^{+}$cells after 2 week exposure), and NKT and NK cells (right panel).

Figure 6. Effect of PFOS exposure at $1.5 \mu \mathrm{g} / \mathrm{kg} / \mathrm{day}$ for 4 weeks on response to influenza infection. (A, D) WT C57BI/6 mice exposed to vehicle or PFOS at $1.5 \mu \mathrm{g} / \mathrm{kg} /$ day were infected with influenza WSN $(\mathbf{A})$, or mixture of $\mathrm{WSN}^{-O V A_{l}}$ and $\mathrm{WSN}^{-O V A_{\|}}(\mathbf{E})$ on day 0 , and weight loss as a percentage of original weight determined over the indicated days. WSN infected $n=4$ (vehicle exposed) and $n=5$ (PFOS exposed), WSN-OVA $A_{l}$ and WSN-OVA W $_{\|} n=7-10$. (B, F) Analysis of

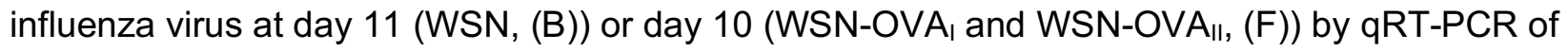
viral genome. (C) Number of lung lymphocytes and granulocytes. (D) Percentage of T cells and granulocytes, $\mathrm{CD}^{+}$and $\mathrm{CD} 8^{+} \mathrm{T}$ cells, and $\mathrm{CD} 44^{\mathrm{Hi}} \mathrm{CD} 4^{+}$and $\mathrm{CD} 8^{+} \mathrm{T}$ cells in $\mathrm{BAL}$ (top panels) and lung (bottom panels). Percentage of lung $\mathrm{TNF}^{+} \mathrm{CD} 4^{+}$and $\mathrm{CD} 8^{+} \mathrm{T}$ cells $\mathrm{T}$ cells (bottom left panel). ${ }^{*} p=0.0346$ for percent lung $C D 4^{+} T$ cells, ${ }^{*} p=0003$ for percent lung $C D 8^{+} T$ cells, ${ }^{*} p=0.0110$ for CD44 ${ }^{\mathrm{Hi}} \mathrm{CD}^{+} \mathrm{T}$ cells. (G) Number of BAL cells following infection with WSN-OVA OVA $_{\| .}$(H) Percentage of OVA/MHCIl tetramer specific CD4s ${ }^{+}$(left panel) and OVA/MHCl tetramer specific CD8 ${ }^{+}$T cells (right panel) in spleen. (I) Number of OVA/MHCII tetramer specific CD4 ${ }^{+}$(left panel) and OVA/MHCl tetramer specific $\mathrm{CD}^{+} \mathrm{T}$ cells (right panel) in spleen. (J) HAl titers of serum from mice used in figure $6 \mathrm{E}$. 


\section{References cited}

1. R. C. Buck, J. Franklin, U. Berger, J. M. Conder, I. T. Cousins, P. de Voogt, A. A. Jensen, K. Kannan, S. A. Mabury and S. P. van Leeuwen, Perfluoroalkyl and polyfluoroalkyl substances in the environment: terminology, classification, and origins, Integr Environ Assess Manag, 2011, 7, 513-541.

2. F. OECD (Paris, Hazard Assessment of Perfluorooctane Sulfonate (PFOS) and Its Salts. , 2002, 1-362.

3. G. W. Olsen, J. M. Burris, D. J. Ehresman, J. W. Froehlich, A. M. Seacat, J. L. Butenhoff and L. R. Zobel, Half-life of serum elimination of perfluorooctanesulfonate, perfluorohexanesulfonate, and perfluorooctanoate in retired fluorochemical production workers, Environ Health Perspect, 2007, 115, 1298-1305.

4. S. C. Chang, P. E. Noker, G. S. Gorman, S. J. Gibson, J. A. Hart, D. J. Ehresman and J. L. Butenhoff, Comparative pharmacokinetics of perfluorooctanesulfonate (PFOS) in rats, mice, and monkeys, Reprod Toxicol, 2012, 33, 428-440.

5. Y. Li, T. Fletcher, D. Mucs, K. Scott, C. H. Lindh, P. Tallving and K. Jakobsson, Halflives of PFOS, PFHxS and PFOA after end of exposure to contaminated drinking water, Occup Environ Med, 2018, 75, 46-51.

6. J. C. DeWitt, S. J. Blossom and L. A. Schaider, Exposure to per-fluoroalkyl and polyfluoroalkyl substances leads to immunotoxicity: epidemiological and toxicological evidence, J Expo Sci Environ Epidemiol, 2019, 29, 148-156.

7. M. A. Verner, A. E. Loccisano, N. H. Morken, M. Yoon, H. Wu, R. McDougall, M. Maisonet, M. Marcus, R. Kishi, C. Miyashita, M. H. Chen, W. S. Hsieh, M. E. Andersen, H. J. Clewell, 3rd and M. P. Longnecker, Associations of Perfluoroalkyl Substances (PFAS) with Lower Birth Weight: An Evaluation of Potential Confounding by Glomerular Filtration Rate Using a Physiologically Based Pharmacokinetic Model (PBPK), Environ Health Perspect, 2015, 123, 1317-1324.

8. E. Negri, F. Metruccio, V. Guercio, L. Tosti, E. Benfenati, R. Bonzi, C. La Vecchia and A. Moretto, Exposure to PFOA and PFOS and fetal growth: a critical merging of toxicological and epidemiological data, Crit Rev Toxicol, 2017, 47, 482-508.

9. C. C. Bach, Z. Liew, B. H. Bech, E. A. Nohr, C. Fei, E. C. Bonefeld-Jorgensen, T. B. Henriksen and J. Olsen, Perfluoroalkyl acids and time to pregnancy revisited: An update from the Danish National Birth Cohort, Environ Health, 2015, 14, 59.

10. V. Ballesteros, O. Costa, C. Iniguez, T. Fletcher, F. Ballester and M. J. Lopez-Espinosa, Exposure to perfluoroalkyl substances and thyroid function in pregnant women and children: A systematic review of epidemiologic studies, Environ Int, 2017, 99, 15-28.

11. E. C. P. E. P. o. C. i. t. F. Chain)., H. K. Knutsen, J. Alexander, L. Barreg ard, M. Bignami, B. Br€uschweiler, S. Ceccatelli, B. Cottrill, M. Dinovi, L. Edler, B. Grasl-Kraupp, C. Hogstrand, L. R. Hoogenboom, C. S. Nebbia, I. P. Oswald, A. Petersen, M. Rose, A.C. Roudot, C. Vleminckx, G. Vollmer, H. Wallace, L. Bodin, J.-P. Cravedi, T. I. Halldorsson, L. S. Haug, N. Johansson, H. van Loveren, P. Gergelova, K. Mackay, S. Levorato, M. van Manen and T. Schwerdtle, Scientific Opinion on the risk to human health related to the presence of perfluorooctanesulfonic acid and perfluorooctanoic acid in food. , EFSA Journal 2018, 16284.

12. N. T. P. Monograph, Immunotoxicity associated with exposure to Perfluorooctanoic Acid or Perfluorooctane Sulfonate, National Toxicology Program Monograph, 2016, https://ntp.niehs.nih.gov/ntp/ohat/pfoa pfos/pfoa pfosmonograph 508.pdf.

13. S. B. Pruett, Quantitative aspects of stress-induced immunomodulation, International immunopharmacology, 2001, 1, 507-520.

14. S. Chang, B. C. Allen, K. L. Andres, D. J. Ehresman, R. Falvo, A. Provencher, G. W. Olsen and J. L. Butenhoff, Evaluation of Serum Lipid, Thyroid, and Hepatic Clinical 
Chemistries in Association With Serum Perfluorooctanesulfonate (PFOS) in Cynomolgus Monkeys After Oral Dosing With Potassium PFOS, Toxicol Sci, 2017, 156, 387-401.

15. D. J. Ehresman, J. W. Froehlich, G. W. Olsen, S. C. Chang and J. L. Butenhoff, Comparison of human whole blood, plasma, and serum matrices for the determination of perfluorooctanesulfonate (PFOS), perfluorooctanoate (PFOA), and other fluorochemicals, Environ Res, 2007, 103, 176-184.

16. C. National Research Council Committee for the Update of the Guide for the and A. Use of Laboratory, in Guide for the Care and Use of Laboratory Animals, ed. th, National Academies Press (US)National Academy of Sciences., Washington (DC), 2011, DOI: 10.17226/12910.

17. D. J. Topham, M. R. Castrucci, F. S. Wingo, G. T. Belz and P. C. Doherty, The role of antigen in the localization of naive, acutely activated, and memory CD8(+) T cells to the lung during influenza pneumonia, J Immunol, 2001, 167, 6983-6990.

18. T. J. Chapman, M. R. Castrucci, R. C. Padrick, L. M. Bradley and D. J. Topham, Antigen-specific and non-specific CD4+ T cell recruitment and proliferation during influenza infection, Virology, 2005, 340, 296-306.

19. Z. Qiu and B. S. Sheridan, Isolating Lymphocytes from the Mouse Small Intestinal Immune System, J Vis Exp, 2018, DOI: 10.3791/57281.

20. J. C. Pedersen, Hemagglutination-inhibition assay for influenza virus subtype identification and the detection and quantitation of serum antibodies to influenza virus, Methods Mol Biol, 2014, 1161, 11-25.

21. E. J. Wherry, M. J. McElhaugh and L. C. Eisenlohr, Generation of CD8(+) T cell memory in response to low, high, and excessive levels of epitope, J Immunol, 2002, 168, 44554461.

22. V. I. Mallet-Designe, T. Stratmann, D. Homann, F. Carbone, M. B. Oldstone and L. Teyton, Detection of low-avidity CD4+ T cells using recombinant artificial APC: following the antiovalbumin immune response, J Immunol, 2003, 170, 123-131.

23. R. Germain, I. Stefanova and J. Dorfman, Self-recognition and the regulation of CD4+ T cell survival., Adv Exp Med Biol 2002, 512, 97-105.

24. M. R. Qazi, B. D. Nelson, J. W. DePierre and M. Abedi-Valugerdi, 28-day dietary exposure of mice to a low total dose $(7 \mathrm{mg} / \mathrm{kg})$ of perfluorooctanesulfonate (PFOS) alters neither the cellular compositions of the thymus and speen nor humoral immune responses: Does the route of administration play a pivitol role in PFOS-induced immunotoxicity?, Toxicology, 2010, 267, 132-139.

25. Q. Y. Lv, B. Wan, L. H. Guo, Y. Yang, X. M. Ren and H. Zhang, In vivo immunotoxicity of perfluorooctane sulfonate in BALB/c mice: Identification of T-cell receptor and calciummediated signaling pathway disruption through gene expression profiling of the spleen, Chem Biol Interact, 2015, 240, 84-93.

26. G. H. Dong, M. M. Liu, D. Wang, L. Zheng, Z. F. Liang and Y. H. Jin, Sub-chronic effect of perfluorooctanesulfonate (PFOS) on the balance of type 1 and type 2 cytokine in adult C57BL6 mice, Arch Toxicol, 2011, 85, 1235-1244.

27. G. H. Dong, Y. H. Zhang, L. Zheng, W. Liu, Y. H. Jin and Q. C. He, Chronic effects of perfluorooctanesulfonate exposure on immunotoxicity in adult male C57BL/6 mice, Arch Toxicol, 2009, 83 805-815.

28. L. Zheng, G. H. Dong, Y. H. Zhang, Z. F. Liang, Y. H. Jin and Q. C. He, Type 1 and Type 2 cytokines imbalance in adult male C57BL/6 mice following a 7-day oral exposure to perfluorooctanesulfonate (PFOS), J Immunotoxicol, 2011, 8, 30-38.

29. M. A. Mollenhauer, S. G. Bradshaw, P. A. Fair, W. D. McGuinn and M. M. PedenAdams, Effects of perfluorooctane sulfonate (PFOS) exposure on markers of inflammation in female B6C3F1 mice, J Environ Sci Health A Tox Hazard Subst Environ Eng, 2011, 46, 97-108. 
30. M. R. Qazi, M. R. Abedi, B. D. Nelson, J. W. DePierre and M. Abedi-Valugerdi, Dietary exposure to perfluorooctanoate or perfluorooctane sulfonate induces hypertrophy in centrilobular hepatocytes and alters the hepatic immune status in mice, International immunopharmacology, 2010, 10, 1420-1427.

31. M. R. Qazi, J. Bogdanska, J. L. Butenhoff, B. D. Nelson, J. W. DePierre and M. AbediValugerdi, High-dose, short-term exposure of mice to perfluorooctanesulfonate (PFOS) or perfluorooctanoate (PFOA) affects the number of circulating neutrophils differently, but enhances the inflammatory responses of macrophages to lipopolysaccharide (LPS) in a similar fashion, Toxicology, 2009, 262, 207-214.

32. M. R. Qazi, Z. Xia, J. Bogdanska, S. C. Chang, D. J. Ehresman, J. L. Butenhoff, B. D. Nelson, J. W. Depierre and M. Abedi-Valugerdi, The atrophy and changes in the cellular compositions of the thymus and spleen observed in mice subjected to short-term exposure to perfluorooctanesulfonate are high-dose phenomena mediated in part by peroxisome proliferator-activated receptor-alpha (PPARalpha), Toxicology, 2009, 260, 68-76.

33. L. Zheng, G. H. Dong, Y. H. Jin and Q. C. He, Immunotoxic changes associated with a 7-day oral exposure to perfluorooctanesulfonate (PFOS) in adult male C57BL/6 mice, Arch Toxicol, 2009, 83, 679-689.

34. M. M. Peden-Adams, J. M. Keller, J. G. Eudaly, J. Berger, G. S. Gilkeson and D. E. Keil, Suppression of humoral immunity in mice following exposure to perfluorooctane sulfonate, Toxicol Sci, 2008, 104, 144-154.

35. H. N. Claman, Corticosteroids and the immune response, Adv Exp Med Biol, 1988, 245, 203-208.

36. M. R. Qazi, M. Hassan, B. D. Nelson, J. W. Depierre and M. Abedi-Valugerdi, Both subacute, moderate-dose and short-term, low-dose dietary exposure of mice to perfluorooctane sulfonate exacerbates concanavalin A-induced hepatitis, Toxicol Lett, 2013, 217, 67-74.

37. J. Bogdanska, D. Borg, M. Sundstrom, U. Bergstrom, K. Halldin, M. Abedi-Valugerdi, A. Bergman, B. Nelson, J. Depierre and S. Nobel, Tissue distribution of (3)(5)S-labelled perfluorooctane sulfonate in adult mice after oral exposure to a low environmentally relevant dose or a high experimental dose, Toxicology, 2011, 284, 54-62.

38. M. R. Qazi, B. D. Nelson, J. W. DePierre and M. Abedi-Valugerdi, High-dose dietary exposure of mice to perfluorooctanoate or perfluorooctane sulfonate exerts toxic effects on myeloid and B-lymphoid cells in the bone marrow and these effects are partially dependent on reduced food consumption, Food Chem Toxicol, 2012, 50, 2955-2963.

39. C. Suo, Z. Fan, L. Zhou and J. Qiu, Perfluorooctane sulfonate affects intestinal immunity against bacterial infection, Sci Rep, 2017, 7, 5166.

40. K. S. Guruge, H. Hikono, N. Shimada, K. Murakami, J. Hasegawa, L. W. Yeung, N. Yamanaka and N. Yamashita, Effect of perfluorooctane sulfonate (PFOS) on influenza A virus-induced mortality in female B6C3F1 mice, J Toxicol Sci, 2009, 34, 687-691.

41. N. M. Bouvier and A. C. Lowen, Animal Models for Influenza Virus Pathogenesis and Transmission, Viruses, 2010, 2, 1530-1563.

42. B. Srivastava, P. Blazejewska, M. Hessmann, D. Bruder, R. Geffers, S. Mauel, A. D. Gruber and K. Schughart, Host genetic background strongly influences the response to influenza a virus infections, PLoS One, 2009, 4, e4857. 
A)

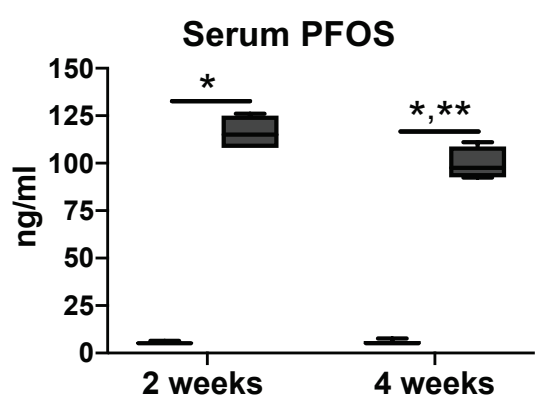

C)
B)

$\square$ Vehicle

$\square$ PFOS
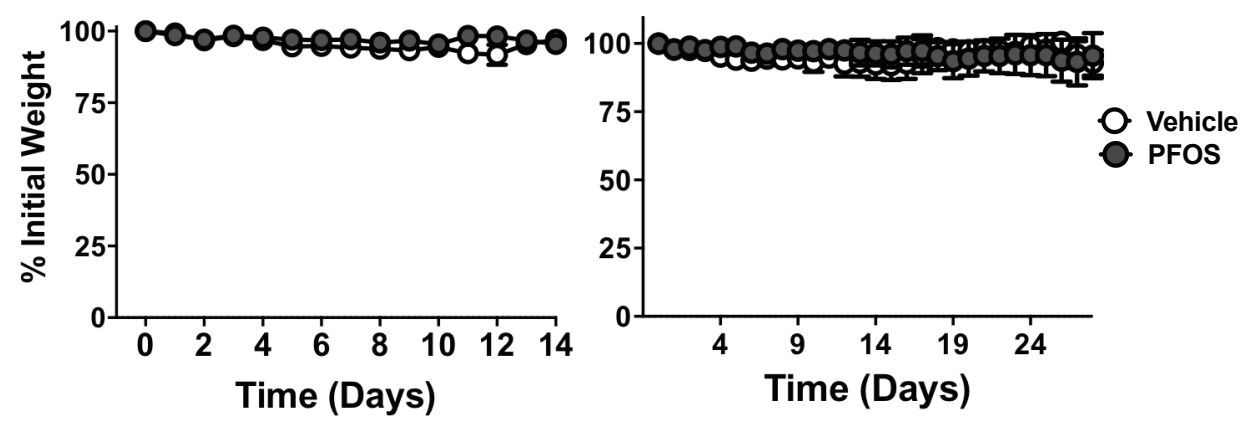

4 weeks

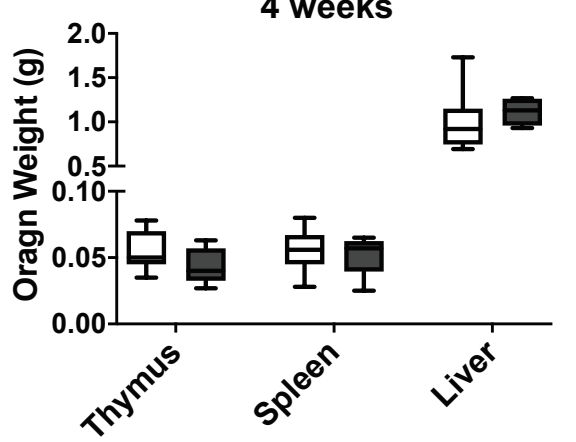

PFOS

Figure 1

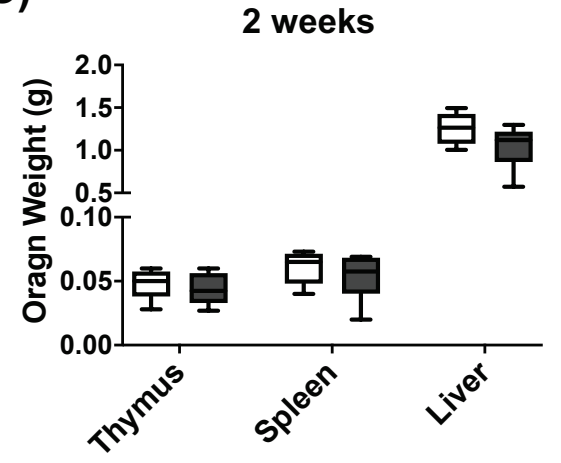


A)
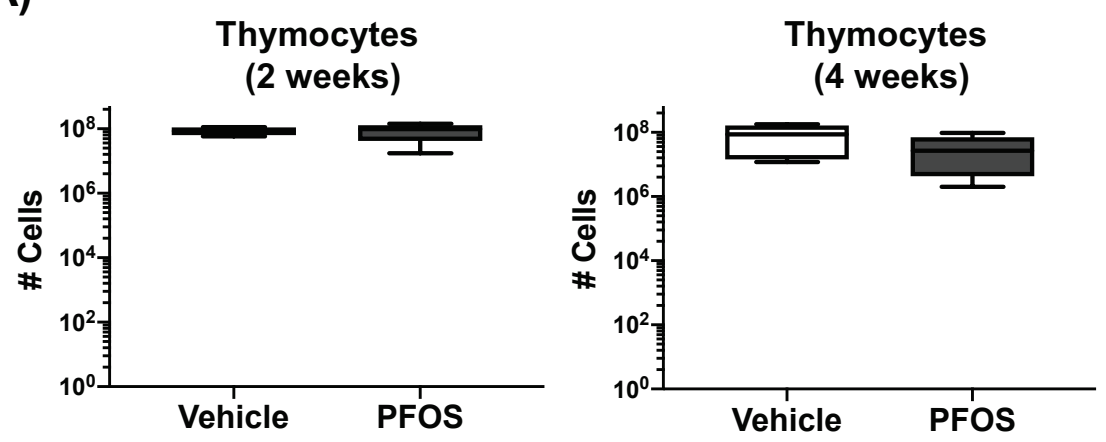

B)
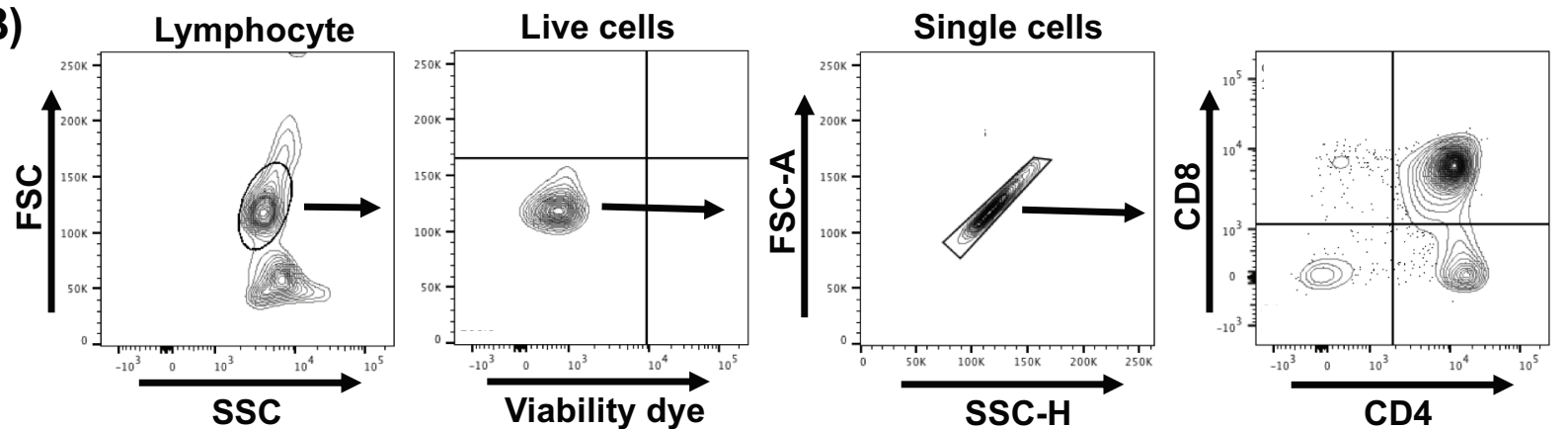

C)

Thymocyte subsets
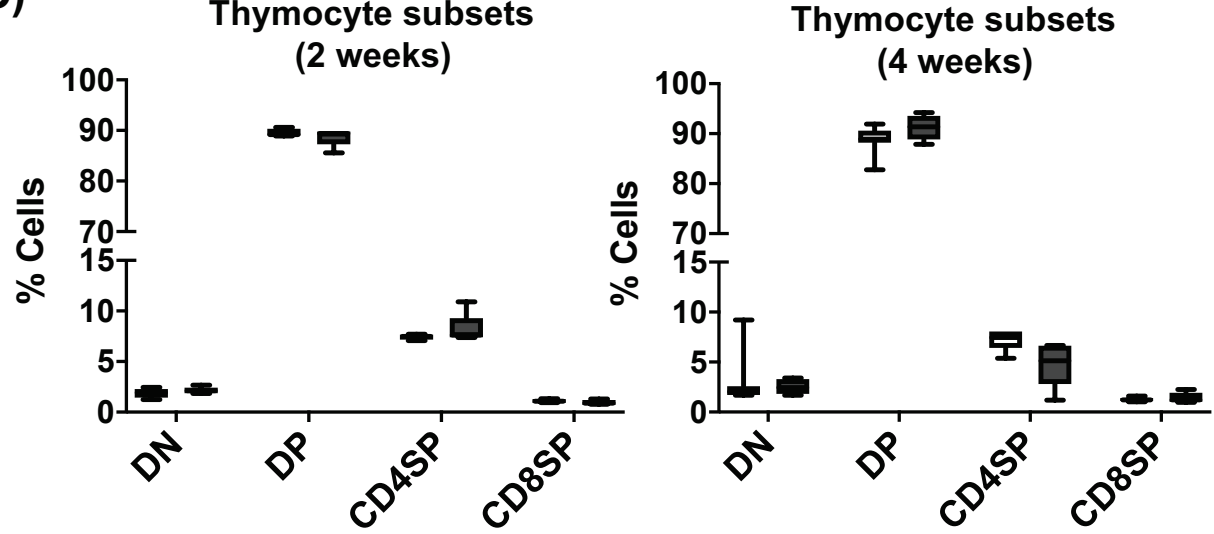

$\square$ Vehicle

$\square$ PFOS

Figure 2 
A)

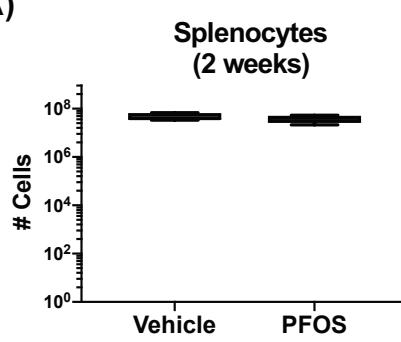

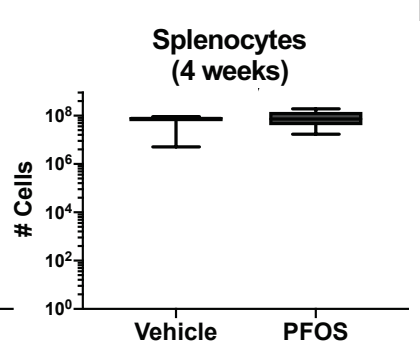

B)

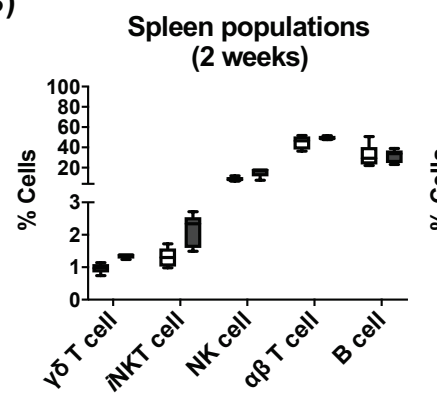

Spleen populations

(4 weeks)

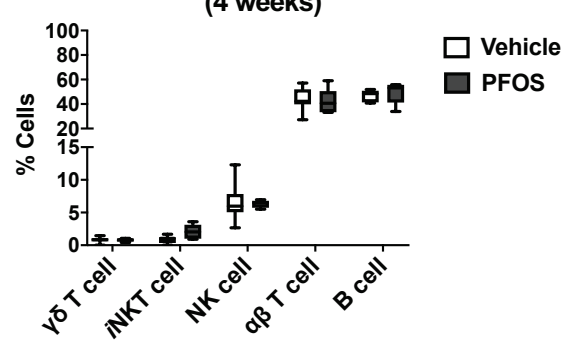

C)
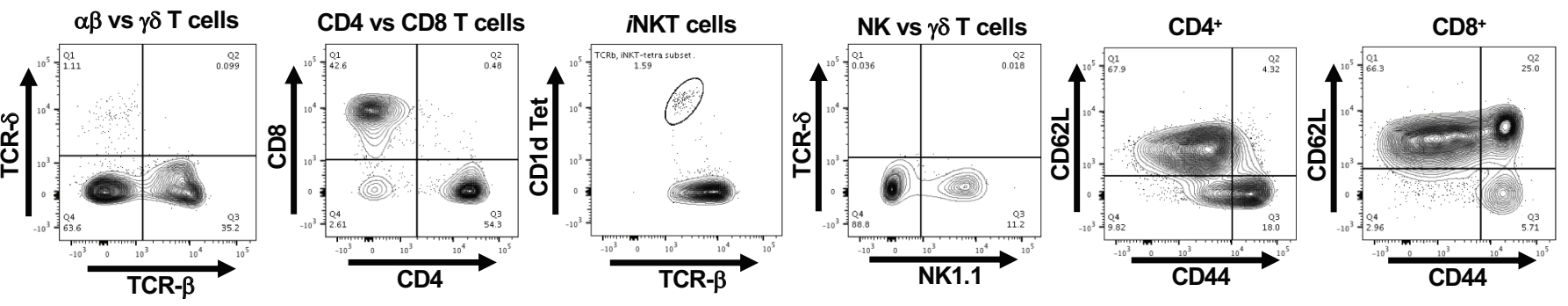

D)
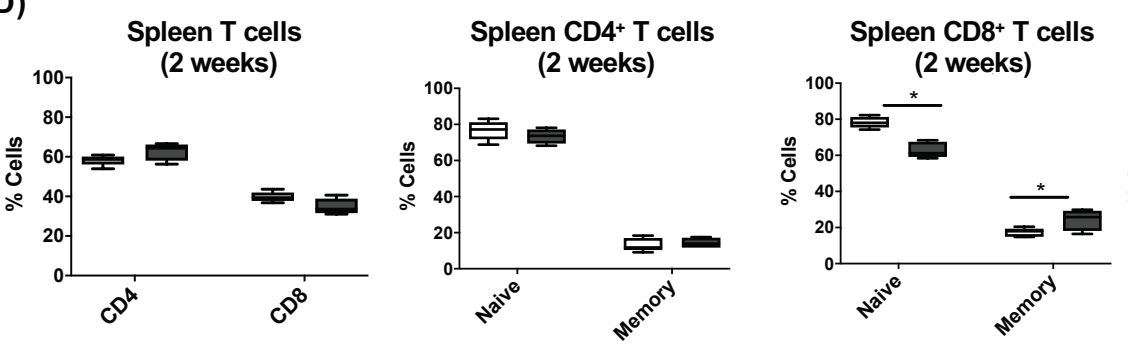

Spleen iNKT and NK cells

Spleen NK cells (2 weeks)
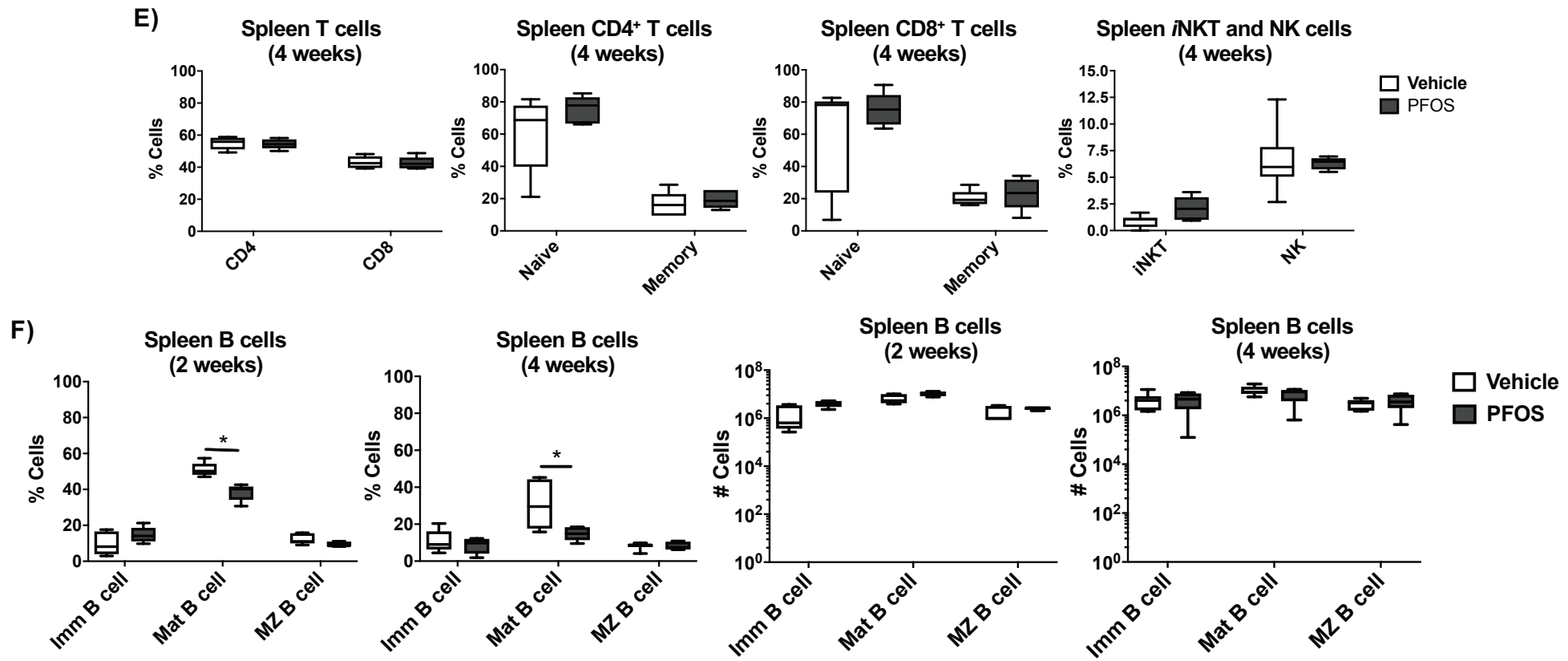

Figure 3 
bioRxiv preprint dol: https://doi.org/10.1101/2020.01.20.913293; this version posted January 24, 2020. The copyright holder for this preprint (which was not certified by peer review) is the author/funder. All rights reserved. No reuse allowed without permission.

A)

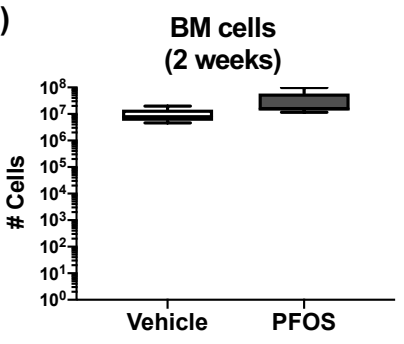

C)

BM B cell population (2 weeks)

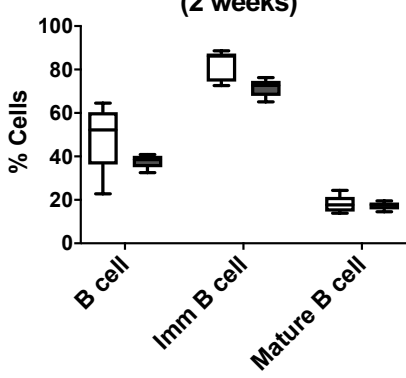

D)

BM cells (4 weeks)

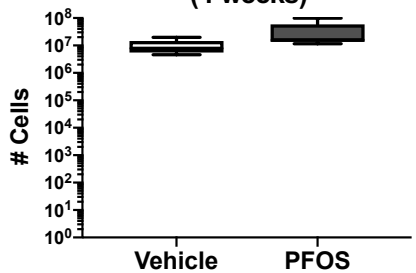

F)

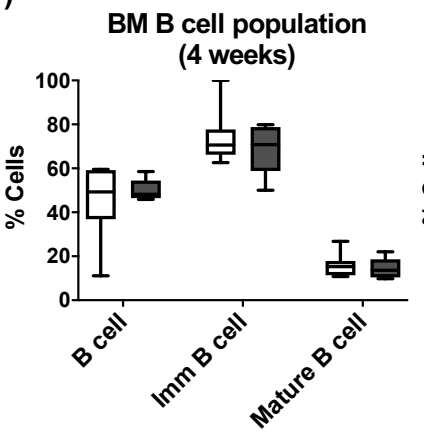

G)

BM iNKS and NK cells

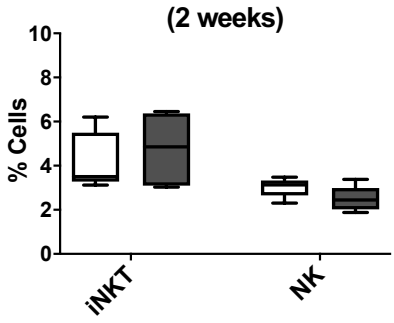

B) BM cell type

(2 weeks)

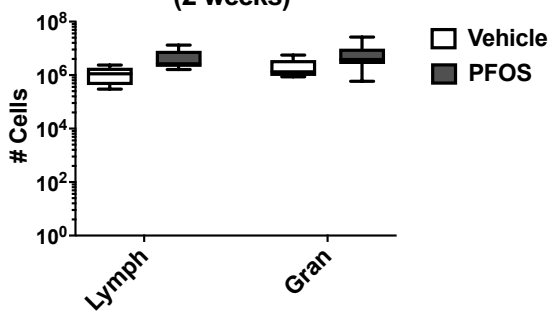

BM $\alpha \beta$ T cells (2 weeks)

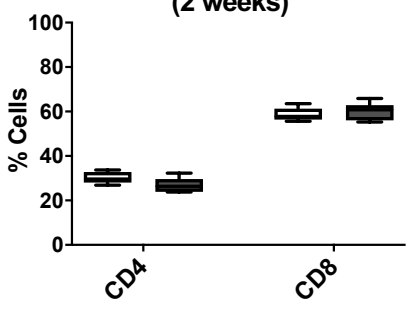

E) BM cell type

(4 weeks)

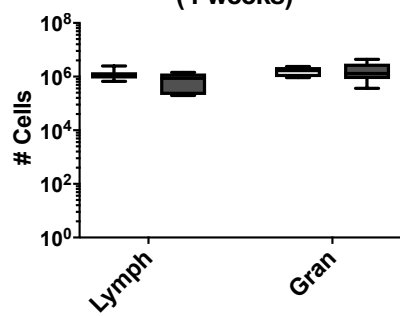

BM $\alpha \beta$ T cells (4 weeks)
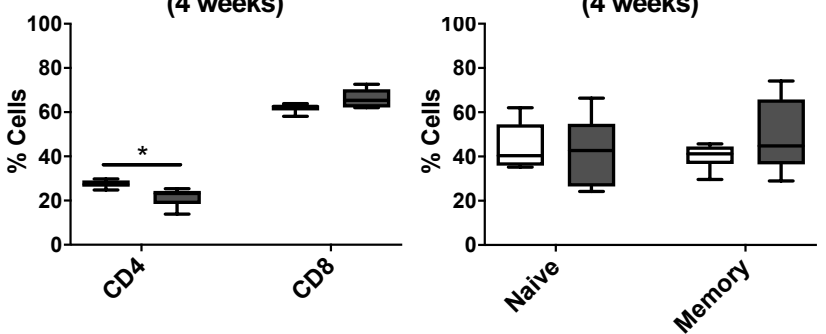

BM NK cells (2 weeks)

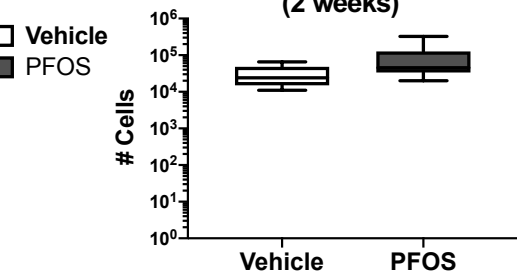

BM B cells

(2 weeks)

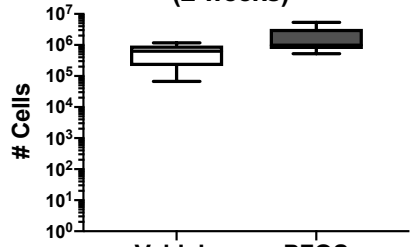

Vehicle PFOS

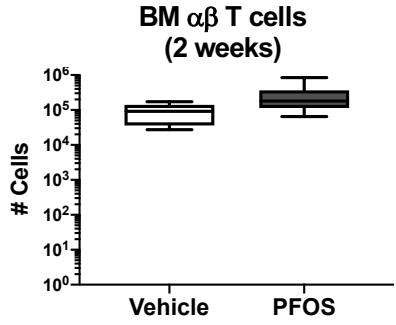

BM CD 8+ cells

(2 weeks)

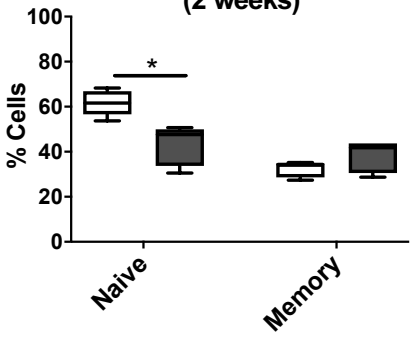

BM B cells (4 weeks)

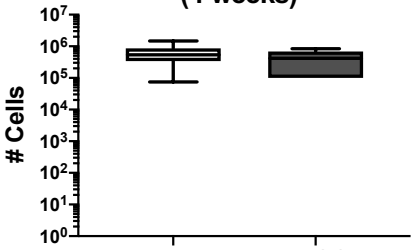

Vehicle PFOS
Vehicle PROS
BM $\alpha \beta$ T cells (4 weeks)

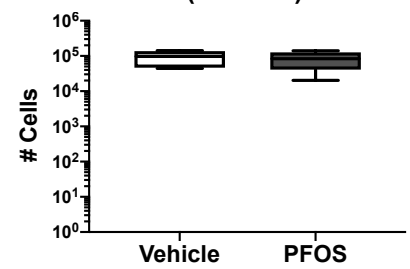

$\mathrm{BM} \mathrm{CD8}{ }^{+}$cells (4 weeks)

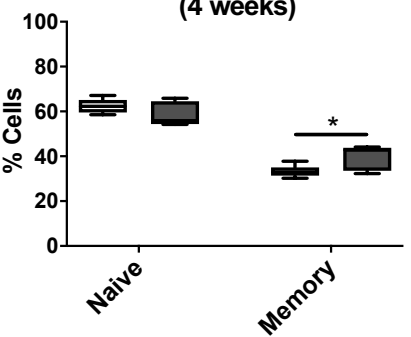

Vehicle PFOS

BM iNK and NK cells (4 weeks)

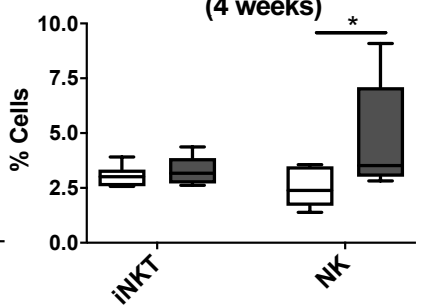

BM NK cells (4 weeks)

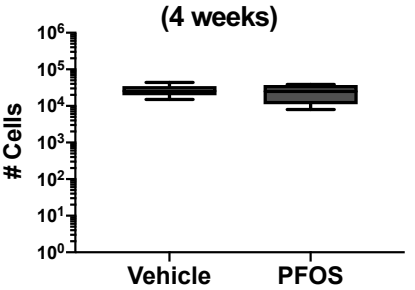

Figure 4 
bioRxiv preprint dol: https://doi.org/10.1101/2020.01.20.913293; this version posted January 24, 2020. The copyright holder for this preprint (which was not certified by peer review) is the author/funder. All rights reserved. No reuse allowed without permission.

A) Liver Lymphoid cells

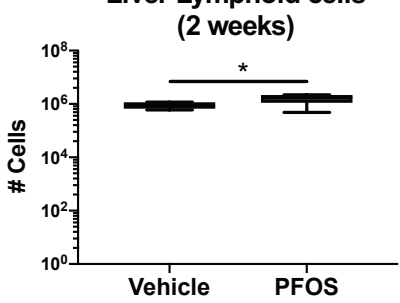

B) Liver $\alpha \beta$ T cells (2 weeks)

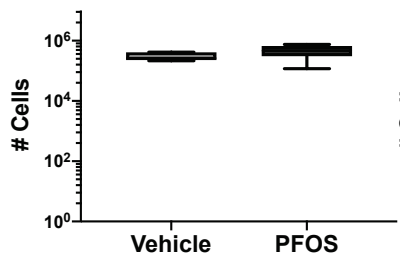

Liver iNKS cells (2 weeks)

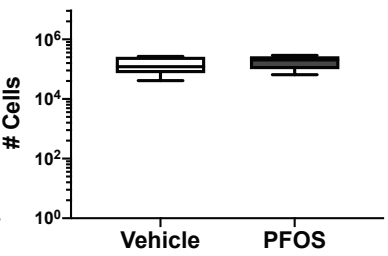

Liver NK cells (2 weeks)

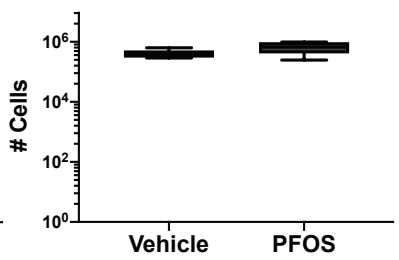

C)

Liver $\alpha \beta$ T cells (2 weeks)

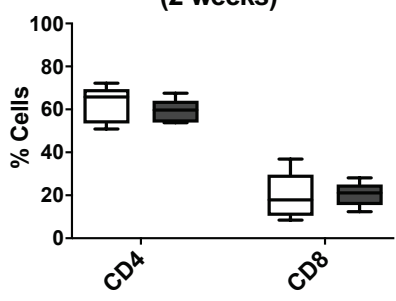

D)

Liver Lymphoid cells (4 weeks)

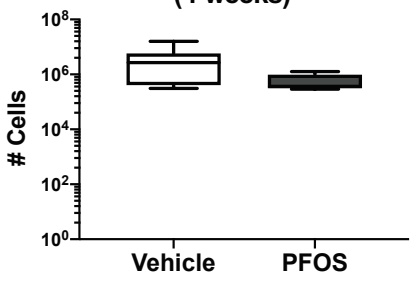

F)

Liver $\alpha \beta$ T cells (4 weeks)

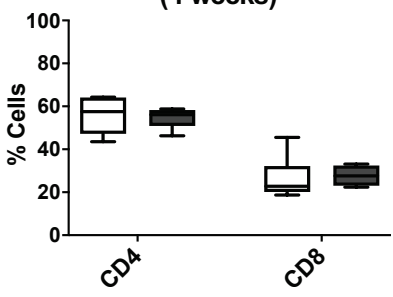

Liver CD4 ${ }^{+} \mathrm{T}$ cells (2 weeks)

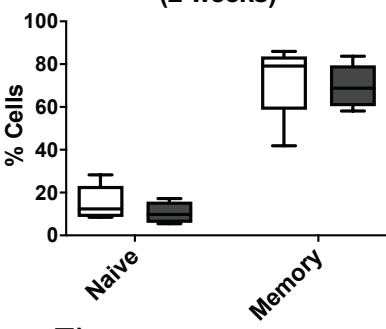

E)

Liver $\alpha \beta$ T cells (4 weeks)

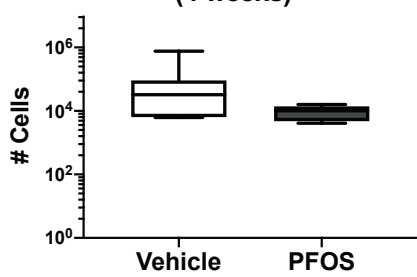

Liver CD8 ${ }^{+} \mathrm{T}$ cells (2 weeks)

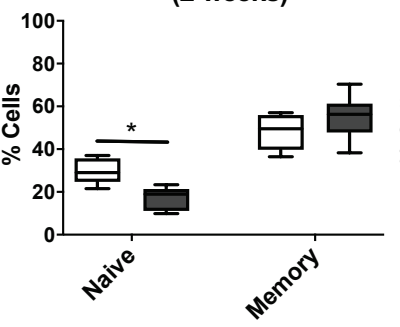

Liver iNKS cells (4 weeks)

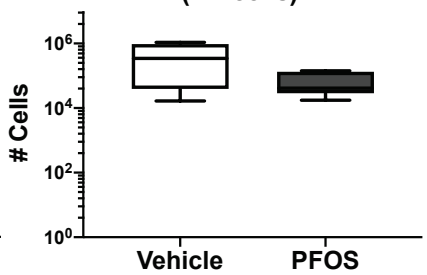

Liver iNKS and NK T cells (2 weeks)

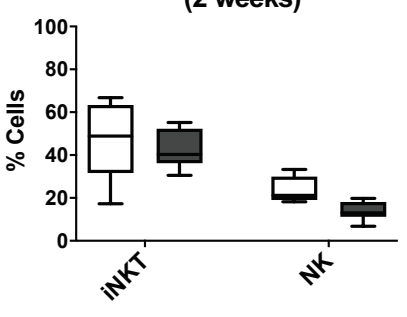

Liver NK cells (4 weeks)

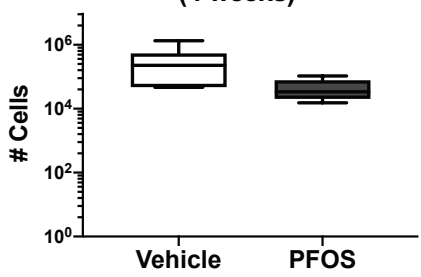

Vehicle PrOS
Liver $\mathrm{CD4}^{+} \mathrm{T}$ cells (4 weeks)

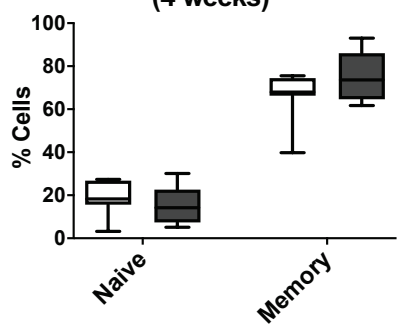

Liver CD 8 ${ }^{+} \mathrm{T}$ cells (4 weeks)

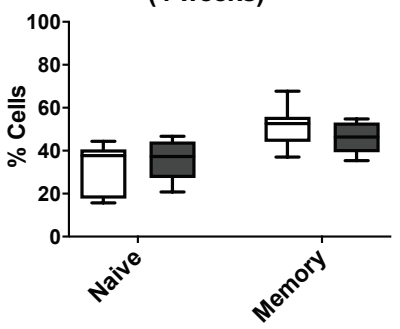

Liver iNKS and NK T cells (4 weeks)

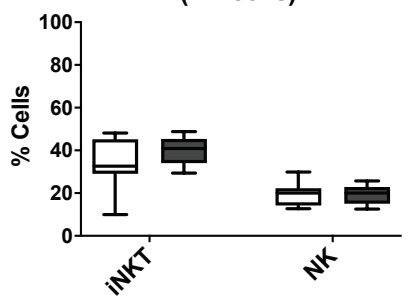

Vehicle

PROS

Figure 5 
A)

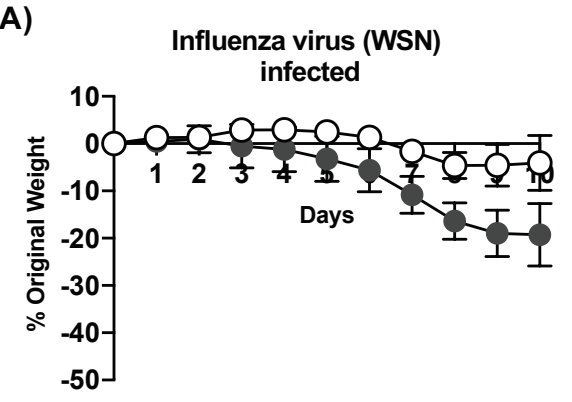

D)

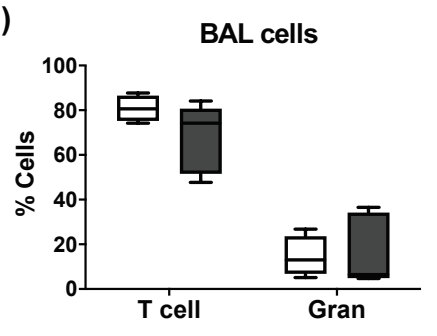

Lung cells

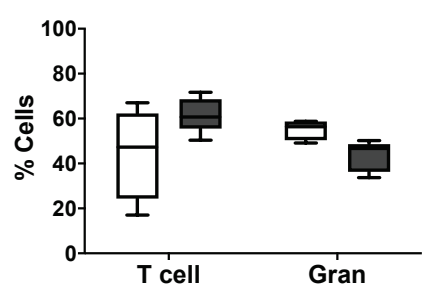

E)

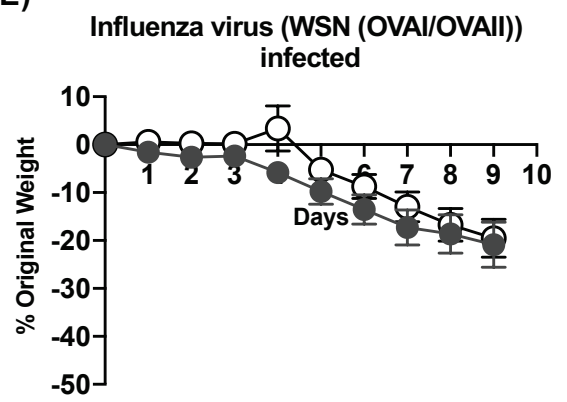

B)

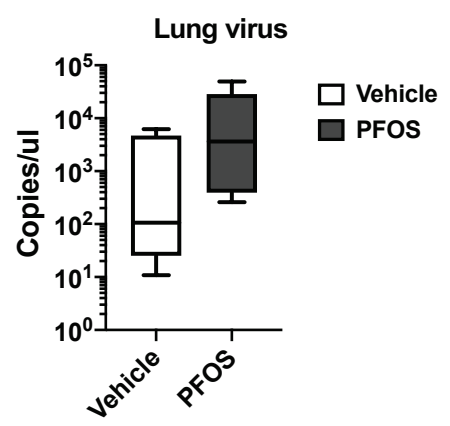

BAL T cells

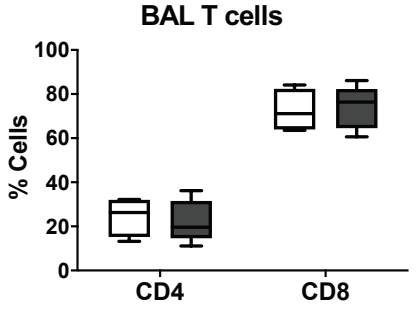

Lung $T$ cells
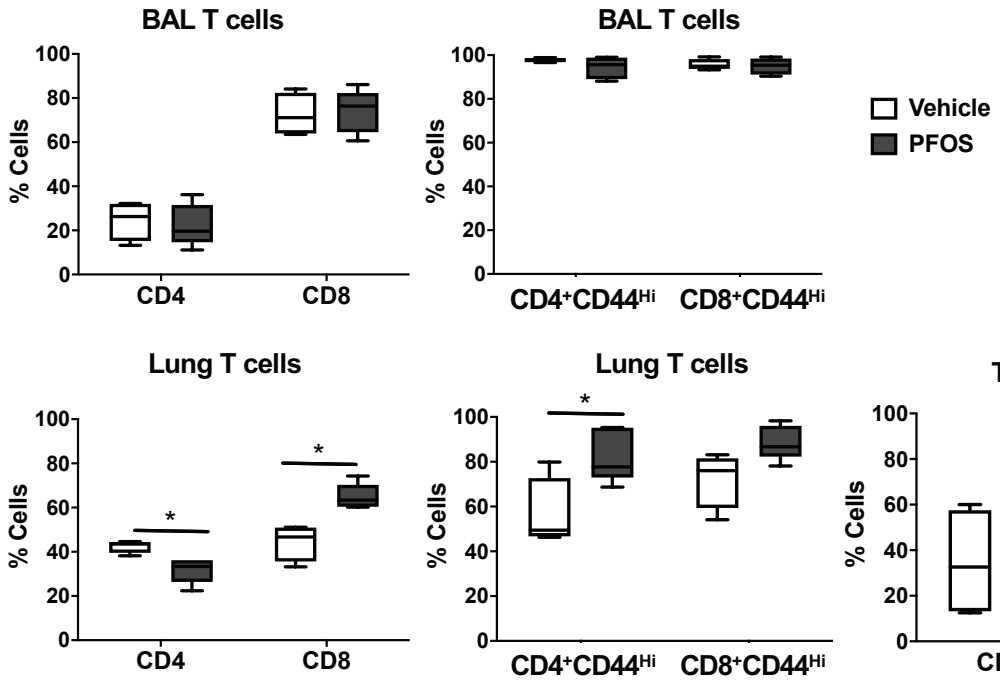

Vehicle

PFOS

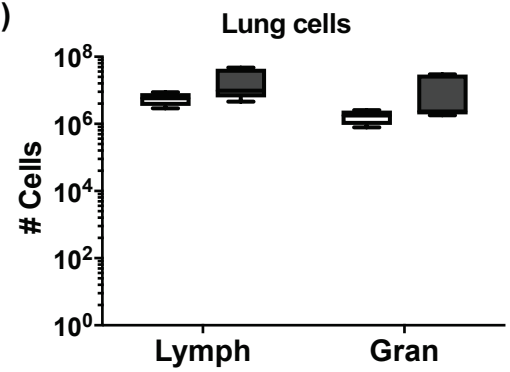

$\mathrm{TNF}^{+}$cells

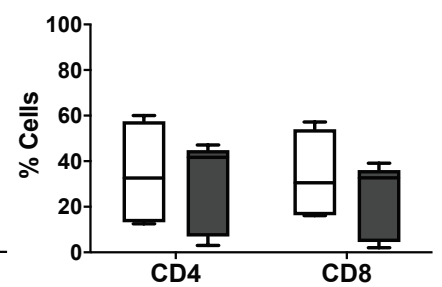

Vehicle $\square$ PFOS

F)

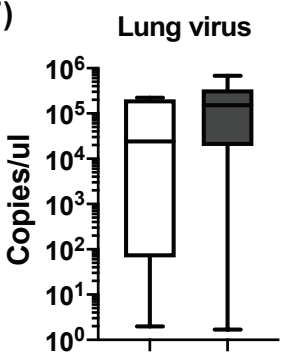

G)

PFOS

Vehicle
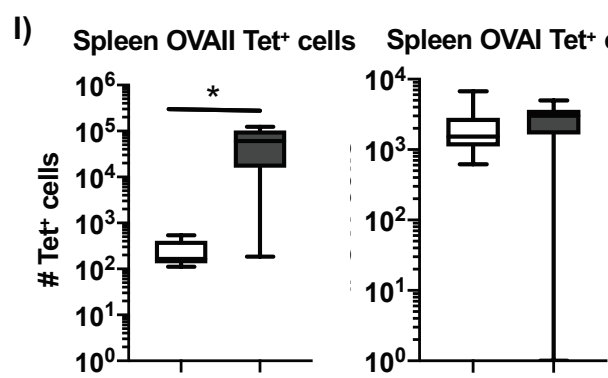

J) Anti-HA virus serum titer

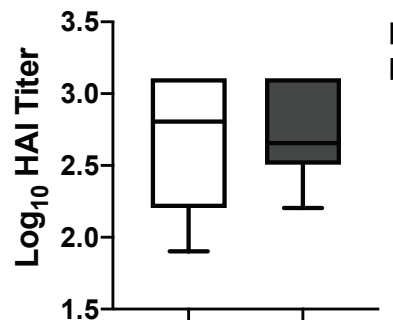

$\square$ Vehicle PFOS 